\title{
DNA repair as a human biomonitoring tool: comet assay approaches.
}

AZQUETA, A., LANGIE, S.A.S., BOUTET-ROBINET, E., DUTHIE, S., LADEIRA, C, M $\varnothing$ LLER, P., COLLINS, A.R. and GODSCHALK, R.W.L. 


\section{DNA repair as a human biomonitoring tool; comet assay approaches}

Amaya Azqueta ${ }^{a(\#)(*)}$, Sabine A.S. Langie ${ }^{b,((\#)}$, Elisa Boutet-Robinet ${ }^{d}$, Susan Duthie, Carina Ladeira ${ }^{f, g}$, Peter Møller ${ }^{h}$, Andrew Collins ${ }^{i}$ and Roger W.L. Godschalkj, on behalf of Working Group 5 of the hCOMET project (CA15132).

aDepartment of Pharmacology and Toxicology, University of Navarra, and IdiSNA, Navarra Institute for Health Research, C/Irunlarrea 1, 31009 Pamplona, Spain;

bVITO -Health, Mol, Belgium;

'Centre for Environmental Sciences, Hasselt University, Hasselt, Belgium;

dToxalim (Research Centre in Food Toxicology), Université de Toulouse, INRA, ENVT, INPPurpan, UPS, Toulouse, France;

eSchool of Pharmacy and Life Sciences, The Robert Gordon University, Riverside East, Garthdee Road, Aberdeen, AB10 7GJ, United Kingdom;

fH\&TRC- Health \& Technology Research Center, ESTeSL- Escola Superior de Tecnologia da Saúde, Instituto Politécnico de Lisboa, Av. D. João II, lote 4.69.01, Parque das Nações, 1990096 Lisboa, Portugal;

'Centro de Investigação e Estudos em Saúde Pública, Escola Nacional de Saúde Pública, Universidade Nova de Lisboa, Portugal;

hDepartment of Public Health, Section of Environmental Health, University of Copenhagen, Øster Farimagsgade 5A, DK-1014 Copenhagen K, Denmark;

'Department of Nutrition, Institute for Basic Medical Sciences, University of Oslo, Sognsvannsveien 9, 0372 Oslo, Norway;

iDepartment of Pharmacology \& Toxicology, School for Nutrition and Translational Research in Metabolism (NUTRIM), Maastricht University, The Netherlands

\#These authors have contributed equally to the paper

${ }^{*}$ Corresponding author

Please address all correspondence to:

Amaya Azqueta

Department of Pharmacology \& Toxicology

School of Pharmacy and NutritionUniversity of Navarra

c/Irunlarrea 1Universiteitssingel 50

31009 Pamplona

Spain

Tel: +34 948425600 (ext. 806343) Email: amazqueta@unav.es 
46 The comet assay offers the opportunity to measure both DNA damage and repair. Various 47 comet assay based methods are available to measure DNA repair activity, but some requirements should be met for their effective use in human biomonitoring studies. These conditions include i) robustness of the assay, ii) sources of inter- and intra-individual variability must be known, iii) DNA repair kinetics should be assessed to optimize sampling timing; and iv) DNA repair in accessible surrogate tissues should reflect repair activity in target tissues prone to carcinogenic effects. DNA repair phenotyping can be performed on frozen and fresh samples, and is a more direct measurement than genomic or transcriptomic approaches. There are mixed reports concerning the regulation of DNA repair by environmental and dietary factors. In general, exposure to genotoxic agents did not change base excision repair (BER) activity, whereas some studies reported that dietary interventions affected BER activity. On the other hand, in vitro and in vivo studies indicated that nucleotide excision repair (NER) can be altered by exposure to genotoxic agents, but studies on other life style related factors, such as diet, are rare. Thus, crucial questions concerning the factors regulating DNA repair and inter-individual variation remain unanswered. Intra-individual variation over a period of days to weeks seems limited, which is favourable for DNA repair phenotyping in biomonitoring studies. Despite this reported low intra-individual variation, timing of sampling remains an issue that needs further investigation. A correlation was reported between the repair activity in easily accessible peripheral blood mononuclear cells (PBMCs) and internal organs for both NER and BER. However, no correlation was found between tumour tissue and blood cells. In conclusion, although comet assay based approaches to measure BER/NER phenotypes are feasible and promising; more work is needed to further optimize their application in human biomonitoring and intervention studies. 


\subsection{DNA damage and repair}

Human DNA is exposed to both exogenous and endogenous agents that can modify its structure. These structural alterations can take different forms: breaks in the sugar-phosphate backbone affecting one or both strands [i.e., single strand breaks (SSBs) or double strand breaks (DSBs)], oxidation or alkylation of bases, large molecules covalently linked to DNA bases (bulky DNA-adducts), proteins linked to DNA bases (protein-DNA cross links), covalent bonds between bases in the same strand (intra-strand cross links) or in different strands (inter-strand cross links), and wrongly paired bases [1]. These DNA lesions can affect transcription but, more importantly, if not repaired or if mis-repaired before the replication process, they can induce mutations. Mutations in key genes (e.g. genes that control DNA repair, DNA replication, cell cycle control or chromosome segregation and apoptosis) are involved in the development of cancer and other degenerative diseases [2].

DNA repair systems, involving different groups of proteins, amend the majority of DNA damages before permanent genome changes can occur. Different DNA repair pathways deal with the various kinds of DNA lesions (see table 1). For instance, SSBs are repaired by the insertion of one or a few bases followed by ligation, while DSBs are repaired by more complicated processes, namely homologous recombination and non-homologous end-joining pathways (the latter being error-prone and therefore potentially mutagenic). Small base alterations such as oxidised and alkylated bases are predominantly repaired by the base excision repair system (BER), involving removal of the damaged base by a specific glycosylase, excision of the resulting baseless sugar, insertion of correct nucleotides using the opposite strand as template and ligation. More complex lesions such as bulky adducts, inter- and intrastrand cross links, and protein-DNA cross links are repaired by the nucleotide excision repair system (NER), in which an oligonucleotide containing the damage is excised and replaced with the correct nucleotides. Finally, wrongly paired bases are repaired by the mismatch repair system. For more details on each DNA repair mechanism, we refer to two comprehensive reviews $[1,4]$.

DNA repair activity is regarded as a valuable human biomarker, reflecting susceptibility to the accumulation of mutations and thus to cancer, the assumption being that a high intrinsic repair activity will reduce the likelihood of damage being present at replication. Repair activity is frequently assessed by measuring the level of transcription of selected genes from different DNA repair pathways or by the detection of gene polymorphisms (the latter often have 
unknown consequences). However, the activity of an enzyme does not entirely depend on transcription and DNA repair is actually regulated in a post-translational manner, so a phenotypic or functional assay is more direct. Moreover, phenotypic analyses take into account the influence of environmental factors. Different phenotypic approaches based on the comet assay have been used to monitor DNA repair in human samples, but the question remains whether these assays are suitable for application in human biomonitoring studies.

The COST Action hCOMET ('The comet assay in human biomonitoring', CA15132, http://www.hcomet.org) with more than 60 researchers from 25 countries is addressing the application of the comet assay (single cell gel electrophoresis) to measure both DNA damage and DNA repair in human samples. This article has been prepared in the framework of this project as a starting point for further validation trials of the comet assay for assessing DNA repair activity. A working group on DNA repair measurements using the comet assay has identified the required conditions for using DNA repair phenotyping in human biomonitoring studies. These conditions include: 1) technical robustness of the assay; analysis of DNA repair activity by the comet assay must have advantages compared to other techniques; 2) sources of inter- and intra-individual variability must be identified; 3) DNA repair kinetics should be assessed to optimize sampling timing; and 4) DNA repair in accessible surrogate tissues should reflect repair activity in target tissues (i.e. tissues prone to carcinogenic effects). Here we describe the current status of these aspects in the scientific literature.

In this review, we predominantly included human biomonitoring studies that focussed on assessing DNA repair activity by comet assay approaches (see next section) in easily accessible tissues or cells. The comet assay-based repair assays are continuously and successfully being validated while at the same time being applied in various research studies. Scientific achievements emerge at the same time as initiatives to understand the assays, improving their reliability, and extending the applications to new tissues. The status of the assays is not advanced to a state where standardized protocols have been adopted. Substantial heterogeneity exists between studies, which very much depends on variation in assay conditions [5]. Although, meta-analysis is an integrate part of systematic reviews, the present variability in the comet assay-based DNA repair assays precludes a meaningful meta-analysis. Thus, only qualitative outcomes of the individual studies will be discussed her.

\subsubsection{The comet assay}


137 Although the alkaline comet assay (single cell gel electophoresis) was primarily developed as a 138 method to measure DNA damage, it has also been used to measure DNA repair. The standard 139 version of the comet assay measures DNA strand breaks (SBs) in individual cells. The protocol 140 is simple [6]: briefly, cells are embedded in agarose, placed on a microscope slide and lysed to remove membranes and soluble components (including histones) leaving nucleoids (i.e., supercoiled DNA attached at intervals to a nuclear matrix forming loops) [7]. After that, nucleoids are exposed to an alkaline treatment and to alkaline electrophoresis. The presence of breaks in the DNA relaxes the supercoiled loops and enables the DNA to migrate towards the anode. Finally, DNA is stained with a DNA fluorescent dye and visualized by fluorescence microscopy, revealing images similar to the stellar comets. The more breaks that are present, the more DNA is able to migrate to the anode. The percentage of DNA in the comet tail represents the frequency of DNA SBs and is measured by image analysis. It is worth to mention that DNA cross-links have the opposite effect; they inhibit the migration of the DNA loops. About 50-150 cells (comets) are evaluated per sample and the mean or median value is normally calculated as the descriptor of the sample. Visual scoring methods have been used, though it is currently not the method of choice. In this system, comets are visually classified in 5 categories according to the intensity of the comet tail and head [8]. Each comet is given a value between 0 and 4; 0 for undamaged comets and 4 for the comets with almost all DNA in their tail. The overall score is calculated by applying the following formula: (percentage of cells in class $0 \times 0)+($ percentage of cells in class $1 \times 1)+($ percentage of cells in class $2 \times 2)+$ (percentage of cells in class $3 \times 3$ ) + (percentage of cells in class $4 \times 4$ ). Consequently, the total score is in the range from 0 to 400 arbitrary units (AU). This system gives reliable results when applied by an experienced operator and is comparable to the scores obtained using image analysis systems [9].

The digestion of the nucleoids (i.e., naked DNA remaining after the lysis of the cells) with lesion specific enzymes allows the detection of other lesions such oxidises bases [10]. Formamidopyrimidine DNA glycosylase ( $\mathrm{Fpg})$ is the most used in order to detect 8-oxo-7,8dihydroguanine (8-oxoGua) though it also detects other DNA lesions.

\subsection{Comet based approaches to measure DNA repair}

\subsubsection{Cellular repair assays}

The most straightforward approach to measure DNA repair activity is to induce DNA damage in 
Interestingly, the comet assay was developed to measure DNA repair from the very beginning; followed the reduction in the number of radiation-induced breaks with time, which represents the repair of those lesions [11]. Singh et al., used what is now referred to as a 'challenge assay' or 'cellular repair assay' (as it will be called in the rest of this paper), which follows the kinetics of removal of a certain DNA lesion and re-ligation of the remaining SB with time (Figure 1) [11]. SB re-ligation following $\mathrm{X}$ - or $\gamma$-irradiation, or $\mathrm{H}_{2} \mathrm{O}_{2}$ treatment has been extensively studied in human biomonitoring [12], but it is possible to monitor the removal of other DNA lesions such as oxidised and alkylated bases, and UV-induced cyclobutane pyrimidine dimers, using appropriate enzymes to convert the lesions to SBs [6]. The specificity of the cellular repair assay, regarding the DNA repair pathway that is measured, depends on the DNA-damaging agent, the version of the comet assay (i.e., with or without enzymes) and the substrate specificity of the enzyme used.

The advantage of this assay is that the entire DNA repair process is assessed, since it depends on the restoration of the normal DNA structure. Moreover, since DNA repair is measured at a cellular level, the presence of cell populations with different DNA repair capacity can in theory be detected. However, from a technical point of view, it is rather complicated to measure repair in this way, because it requires hours of cell culture and sampling at intervals for comet assay analysis, highly limiting the number of samples that can be analysed at the same time.

The fact that cells (normally white blood cells) are under ex vivo conditions might also influence the DNA repair process. Although there is no direct evidence to support this notion, the higher ex vivo oxygen tension, compared to the in vivo conditions, could for instance alter the repair process. Moreover, interpretation of the results is complicated by the fact that DNAdamaging agents may induce different amounts of lesions in different subjects, so that repair starts at different substrate concentrations [12]. This may be particularly important if the initial amount of damage is too high, reaching the point of saturation of the comet assay.

\subsubsection{Inhibitor-based cellular repair assay}

DNA repair capacity can also be measured by including polymerase inhibitors such as aphidicolin or cytosine arabinoside in the cellular repair assay; in this way, removal of the affected nucleotide occurs, but the re-synthesis step to fill the gap in DNA is inhibited [13-15]. As a result, the normally transient SBs accumulate to an extent which reflects the repair capacity of the cells. Although from a technical point of view this assay is simple, its application in human biomonitoring studies is very rare. The assay has been successfully used to assess 
NER capacity $[14,15]$, but it is worth mentioning that some authors have reported that the

204 DNA breaks produced during NER are not necessarily transient in freshly isolated lymphocytes

205 and are detectable with the comet assay without using additional polymerase inhibitors [16,

206 17]. In any case, the use of polymerase inhibitors may increase the sensitivity of the assay by

207 increasing the \%DNA in the tail and avoids misinterpretation of the results (e.g. inter-individual

208 differences resulting from different precursor pool sizes rather than actual differences in

209 repair). The application of this method to biomonitoring requires further investigation and 210 validation.

211

\subsubsection{In vitro DNA repair assays}

213 As an alternative to assessing repair carried out by intact cells, a more biochemical approach 214 referred to as in vitro DNA repair assay- has been developed. This approach is based on the capability of repair proteins in a cell extract to recognize and incise substrate DNA that contains specific lesions. The whole-cell extract can be prepared from lymphocytes, ground tissues or cultured cells, by 'snap-freezing' and subsequent lysis with Triton X-100. At the moment, there are distinct types of in vitro DNA repair assay.

One of these approaches uses closed circular plasmids containing specific lesions as substrate. When incubated with the cell extract, repair enzymes within this extract can incise the plasmid close to the lesion and the resulting nicked (repaired) or closed (unrepaired) plasmids can be separated by gel electrophoresis [18]. In an alternative version of this plasmid assay, the cell extract is incubated with the plasmid in the presence of ${ }^{32} \mathrm{P}$-labelled deoxyribonucleoside triphosphates and repair can be estimated by the incorporation of radioactive precursors into a repair patch [19]. In this way the plasmid assay measures the overall repair starting from incision to repair synthesis. Alternatively, the cell extract can be incubated with an oligonucleotide that is constructed with a specific DNA lesion and a terminal radioactive or fluorescent tag $[20,21]$. The repair enzymes in the extract will cut the oligonucleotide at the damaged site, causing the release of the label or a change in the size of the single stranded oligonucleotide, which can be measured as an indicator for DNA repair.

Although these methods have been applied in human biomonitoring studies, especially by Paz-Elizur et al. ([22-24]) and Leitner-Dagan, et al. ([25, 26]), the number of studies in which these techniques were applied is limited. The comet assay on the other hand has been used as an in vitro DNA repair assay more often and its principle plus multiple applications has recently 
236 it with agarose-embedded nucleoids containing specific lesions as substrate (nucleoids can be

237 derived from established cell lines or white blood cells) (Figure 2). The DNA repair enzymes in 238 the cell extracts will recognize the damage in the substrate nucleoids and induce repair 239 incisions. The comet assay reveals the incision activity of the enzymes by the accumulation of 240 breaks in the substrate nucleoids. (It seems that the pool of deoxynucleotide triphosphates 241 (dNTPs) in peripheral blood mononuclear cells (PBMC) is so limited and diluted that the re242 synthesis stage of DNA repair cannot take place. When dNTPs are added to the cellular extract, 243 DNA synthesis and ligation occurs and breaks/incisions are no longer detected [27].

244 Thus, the nature of the DNA lesions in the substrate defines the type of DNA repair that is 245 measured. BER and NER have been extensively studied using this approach [28]. In the case of 246 the in vitro BER assay, substrate nucleoids are commonly produced by treating cells with the 247 photosensitiser Ro 19-8022 and subsequent irradiation with visible light or cells are treated 248 with potassium bromate to produce 8-oxoguanine (8-oxoG) $[29,30]$. For the in vitro NER 249 assay, substrate nucleoids are produced by treating cells with benzo[a]pyrene-diol epoxide 250 (BPDE) to induce bulky adducts [31], with UV(C) to induce pyrimidine dimers [32], or with 251 oxiplatin to induce cross-links [33]. In these in vitro assays, the incision activity is considered to 252 be the rate-limiting step of the DNA repair process, and is measured as an indicator of the DNA 253 repair activity. This method is more convenient for human biomonitoring studies than the 254 cellular assay, since several samples can be easily analysed at the same time and it can be 255 performed with frozen samples [34]. Most of the publications using the in vitro repair assay to 256 measure DNA repair activity in humans use lymphocytes or PBMCs. There are few human 257 studies using tissue samples; to the best of our knowledge only colon has been analysed [33, $25835,36]$.

\section{Technical validation and optimizations}

The cellular repair comet assay and the in vitro repair comet assay for BER and NER have been extensively used in assessing DNA repair for biomonitoring purposes. However, although several protocols regarding the different approaches have been published, most laboratories use their own protocols, which leads to significant variations in procedures and potential difficulties in carrying out inter-laboratory comparisons of results. In fact, all techniques used in molecular epidemiology should be validated before routine use, so that there can be confidence in the results, and comparability between laboratories and studies. 


\subsection{Cellular repair assay - optimizations \& lack of validation}

270 Protocols to carry out the cellular repair assay, covering the measurement of repair of SBs, 271 oxidised bases (BER) and UV-induced pyrimidine dimers (NER), were published by Collins and 272 Azqueta [37]. As mentioned in the introduction, this is a simple but tedious approach. 273 According to our knowledge, though the approach has been extensively used, validation 274 studies have not been carried out (or published) and there are still some pending technical 275 issues. Foremost, the effect of the type of DNA-damaging agent on DNA repair activity has not been tested (e.g. X-, y-irradiation, vs. $\mathrm{H}_{2} \mathrm{O}_{2}$ to induce $\mathrm{SBs}$; different photosensitisers plus light vs. potassium bromate to induce oxidised bases; UVC-light vs. BPDE to induce lesions repaired by NER). Additionally, analysis of results is an issue since individuals can vary in the level of damage induced experimentally in the test cells, due to differing individual susceptibility to the DNA-damaging agent (e.g. varying antioxidant status leading to different levels of base oxidation). Therefore, the use of $t^{1} / 2$ (i.e. the period of time at which half of the DNA damage has been repaired) could be a good option in order to compare results among different individuals, assuming first order kinetics, because $t^{1} / 2$ may be independent of the initial amount of damage [37].

The approach of measuring DNA repair by blocking polymerase and re-ligation after incision using DNA polymerase inhibitors has been described as a potential tool to be used in human biomonitoring studies, but it has not yet been applied in large scale studies [15, 38]. It presents the same unsolved technical issues as the cellular repair assay.

\subsection{The validity of the in vitro repair assay}

291 Collins and Azqueta described the practical details for applying the in vitro repair assay [37] 292 and a detailed protocol to carry out this assay in cultured cell lines, blood cells, animal tissues 293 and human biopsies, was published in 2013 [34]. The protocol includes practical tips and 294 recommendation for setting up the assays. This is the most convenient adaptation of the 295 comet assay to measure DNA repair in human biomonitoring studies and several technical validations have been carried out. The usefulness of the in vitro BER assay was demonstrated several times since the very first paper in which the approach was described, measuring the repair activity of extracts from cells/tissues of OGG1 knockout cells and mice in comparison to wild type (WT) material. In all cases the activity decreased or completely disappeared in knockout samples [29, 36, 39, 40]. The usefulness of the in vitro repair assay to assess NER activity was demonstrated by Langie et 
al. using extracts of cell lines established from patients with xeroderma pigmentosum (XPA-/-, XPC-/-) and WT fibroblasts [31]. They found lower DNA incision activity when extracts from the knockout cells were used and, as expected, the activity was restored to normal WT values when mixing the extracts of XPC and XPA mutants, because they complement each other. Slyskova et al. measured the NER repair activity of extract from liver of XPG-/- and WT mice, showing that knockout mice had no more activity than the negative control incubations with reaction buffer alone [36].

The protein concentration of extracts can be measured and concentration adjusted, though Collins et al. reckoned that determining the extract concentration on basis of the cell numbers is sufficiently accurate when using lymphocytes [29]. However, in some cases cells are lost during centrifugation; and the extraction efficiency of proteins can differ slightly between batches. Therefore, it is recommended that the concentration of proteins should be measured in each extract [34]. In the case of extracts from tissues, the protein estimation is essential [40, 41], since tissue samples consist of an unknown number of cells, containing a mixture of cell types and connective tissue.

The incision activity at different extract protein concentrations normally shows a non-linear relation or a linear but not proportional relationship between incision and concentration. Collins et al., showed a linear but not proportional relationship of extract concentration and BER activity when 0.25X, 0.5X and $1 \mathrm{X}$ extract was used [29]. Guarnieri et al. also found a linear but non-proportional relationship when testing the BER activity of different mouse liver extract concentrations (0.001, 0.01, 0.1 and $1 \mathrm{x}$ ) [39]. In an experiment testing different concentrations of extract from human colon biopsies (0-18 $\mathrm{mg}$ protein $/ \mathrm{ml}$ ), a non-linear relationship was reported: a non-proportional increase in activity was seen until $3 \mathrm{mg} / \mathrm{mL}$ followed by a decrease at higher concentrations [36]. The authors explained that too high protein concentration saturated the reaction. In the same study, similar effects were observed when the NER incision activity was measured. Likewise, when testing human lymphocytes or cultured fibroblast for their NER activity; high protein concentrations caused a lower relative difference between the total damage-related incision activity and non-specific incisions [31]. Therefore, when working with tissues, extract dilution curves should be performed to elucidate the protein concentration showing the maximum activity, since important differences in the optimal concentration among tissues (especially between proliferative and non-proliferative tissues) have been shown in animals [40, 41]. This probably also applies when using human tissues. 
Heat inactivation of extracts from animal tissues demonstrated that the SBs in substrate DNA are produced by enzymes contained in the extract and so the assay is measuring enzyme activity [40-42]. Slyskova et al. used aphidicolin or ABT888, inhibitors of the post-incision (repair synthesis) phase of BER and NER respectively, to check if they could increase the specificity of the assay and prevent underestimation of the detected incision activity of the protein extracts (from human colon biopsies) [36]. Incision activity could be underestimated due to the presence of some level of repair synthesis occurring. However, if that were the case, the inhibitors would have enhanced the yield of breaks, but this was not observed [36].

The lack of non-specific nucleases in extracts from lymphocytes has been demonstrated by the low level of SBs present in untreated substrates [29]. However, significant non-specific nuclease activity was detected in extracts from animal tissues $[40,41]$. In this case, altering the reaction buffer was used as strategy to decrease the non-specific enzyme activity (adding proteinase inhibitors, ATP, polyAT) [40, 41]. Although these changes decreased the nonspecific nuclease activity, a simultaneous decrease in repair-specific incision activity was observed. Interestingly, aphidicolin may have an inhibitory effect on various nucleases that are not related to DNA repair processes. For instance it had been demonstrated to inhibit Herpes Simplex virus DNA polymerase-associated nuclease activity [43], as well as the $3^{\prime} \rightarrow 5^{\prime}$ exonuclease activity of eukaryotic polymerases $\delta$ and $\varepsilon[44,45]$. Only the use of aphidicolin significantly increased the specific incision activity of mouse liver and brain extracts by decreasing the non-specific endonuclease activity in the BER assay [40], but did not have such an effect in mouse colon and lung [41]. To reduce non-specific incision activity in mouse colon and lung the protein concentration of extracts had to be decreased or additional washes during extraction had to be performed [41].

The reproducibility or inter-experimental variability of the assay has also been demonstrated for different types of samples (lymphocytes and colon biopsies) for both the in vitro BER and in vitro NER assay by analysing duplicate samples on different days [29, 31, 32, 36]. This indicates that the repair activity is stable after storage of samples. Similarly, long-term preservation of animal tissues and extracts to be used in the in vitro DNA repair assays has been demonstrated for BER [40]. Regarding the NER assay, the situation depends on the storage of the sample; either as cell pellet or protein extract, plus the addition of ATP to the extract. The use of ATP or an ATP-regenerating system in the extract is not needed when the BER assay is carried out in lymphocytes [29]. When assessing NER incision activity similar results have been obtained with or without adding ATP to freshly prepared cell extracts [31, 32], demonstrating that samples contain enough ATP to carry out the first reactions of the repair process. However, Langie et 
al. showed that protein extracts lose their activity after long-term storage (i.e. several weeks)

370 at $-80^{\circ} \mathrm{C}$ and that activity is restored by adding ATP [31]. Cell pellets stored at $-20^{\circ} \mathrm{C}$ kept their

371 activity for at least 40 days and the addition of ATP did not increase activity [31]. Some authors

372 claim that magnesium is essential for the detection of NER activity [32]. However, it is

373 advisable to test this for each new cell type or tissue under study, as a too high magnesium

374 concentration in the extract could enhance non-specific nuclease activity, as demonstrated in the BER assay when using mouse tissue extracts [40, 41].

376

\subsection{Crucial parameters to consider}

378

The incubation time of the extract with the substrate is a critical parameter of the assay; timecourse experiments showed an initial linear increase in SBs followed by a plateau [29]. The optimal time of incubation should be selected from the linear part of the curve, but showing a high enough BER or NER incision activity. Several incubation times have been reported, many of them based on preliminary studies $[31,39,40]$. These variations in incubation times could be partially due to the different adopted incubation methods; some researchers use humid boxes placed in an incubator, while others use a 'slide moat'. It is crucial to select an incubation time which detects enzyme or extract activity in the linear phase of the titration curve, not to reach the plateau.

Langie et al., studied the effect of varying the agarose concentration in the BER assay; the agarose concentration may affect the penetration of the enzyme and in consequence the incision repair activity of, in this case, mouse liver extracts [40]. Indeed, an inter-laboratory comparison was published in 2013 [46], in which the incubation step of the nucleoids with the repair extract seemed to be an important stage in the protocol that led to large interlaboratory variation. In this trial, 8 laboratories tested the BER activity of three cell lines starting with cell pellets or with cell extracts, both provided by the coordinating laboratory. The 6 most experienced laboratories reported the same cell line as having the highest activity. A significant correlation was reported between the repair activity found when testing the provided extract and the self-made extract from the provided cell pellet; this suggests that the predominant source for inter-laboratory variation was the incubation of the extract with the substrate. Though detailed instructions were given to prepare the cell extract or to assess the repair activity of the provided and self-made extracts, each laboratory used their own 
particular steps (i.e., agarose concentration and extract incubation) and the penetration of repair enzymes into the gel.

403

\subsection{Outstanding issues that warrant further technical investigation}

405 In the protocol published by Azqueta et al., some outstanding technical issues were noted [34].

406 These and additional technical issues are outlined below:

407 1) DNA incision activity can be studied in relation to the number of cells in the extract, the 408 protein concentration or the DNA content, but the accuracy of the different options has not 409 been studied.

410 2) Although, aphidicolin is mainly known as a DNA polymerase inhibitor, the use of aphidicolin 411 in cell extracts also prevents the occurrence of non-specific nuclease activity in the BER assay 412 [40]. Aphidicolin was described to have an inhibitory effect on various nucleases that do not 413 have a specific role in DNA repair processes. However, its effect when the NER assay is carried 414 out has only been tested once with human colon biopsies [36]. In some cases, it may enhance the detection of NER activity by preventing repair synthesis [40].

3) There is a lack of proportionality between repair activity and protein concentration, which needs to be further investigated. Meanwhile, it is recommended that as far as possible extracts should be made from the same number of cells or the same wet weight of tissue, and resulting protein concentrations should be checked.

4) The in vitro repair assay needs to be validated by comparison with other in vitro assays. Some efforts have been made in this direction as is stated in the next section.

5) A new 'ring study' involving several laboratories, standard cell extracts and standard protocols should be carried out.

6) The most widely used substrate for the in vitro repair assay has been Ro19-8022 + light. However, potassium bromate is an easier and cheaper chemical to use. This substrate has been used for repair activity in cell cultures [47] and human biomonitoring studies [30]. Interestingly, potassium bromate generates equally high levels of DNA lesions detectable in the hOGG1- and Fpg-modified comet assay, whereas Ro19-8022 + light seems to generate lower levels of hOGG1-sensitive sites as compared to Fpg-sensitive sites [48]. This discrepancy remains to be investigated.

431 7) For the NER assay, both UV light and BPDE have been used to produce substrate nucleoids, 432 and the relationship between the two has not been properly studied; cyclobutane pyrimidine 
dimers and bulky DNA adducts are not necessarily recognised in the same way by repair enzymes.

435 8) It has not been studied so far whether the use of different cell types to produce the 436 substrates (e.g. different established cell lines or human lymphocytes) has any influence on the 437 measurement of DNA repair.

438 9) There is a lack of true positive controls: i.e., compound that increases the cellular repair for 439 the cellular repair assay, or extracts with a high repair activity for the in vitro repair assay. This 440 may be a complicated issue since the induction/modulation of the DNA repair may depends on 441 the cells line/tissue under study. However, some attention should be given to this point. Over 442 recent years, different versions of the alkaline comet assay have been developed in order to 443 increase the throughput. For example, a medium throughput comet assay has been 444 successfully used in an updated version of the in vitro BER and in vitro NER repair assays, using 44512 minigels on microscope slides $[34,36,49]$, or 8 deposits on GelBond ${ }^{\circledR}$ films for the 446 Aphidicolin-block cellular repair assay [50, 51]. More recently, further adaptations enable high 447 throughput performance of the comet assay. For example, the use of larger Gelbond ${ }^{\circledast}$ films 448 and reduction of the volume of agarose deposited offer the possibility to increase to 96 449 minigels processed on the same support [52], but this method has not yet been applied to the 450 repair assays. Other technologies derived from the comet assay, using high throughput 451 microarray or microfluidic approaches, have been proposed to study DNA damage, for 452 example CometChip [53], Microfluidic Comet Array [54] and HaloChip [55]. These techniques 453 have been applied to the cellular repair assay, but to date they are not applicable to the in 454 vitro repair assay, either for NER or for BER.

455 High throughput is crucial for human biomonitoring to allow the processing of a high number 456 of samples. A new challenge is to adapt either the high throughput comet assay or one of the 457 newer derived technologies in order to make it useful not only for the cellular repair assay but 458 also for the in vitro DNA repair assays.

\section{3. Comparison of techniques and comparison BER/NER}

461 Comparing techniques with each other, preferably comparing a newly developed assay with a gold standard, is a crucial aspect of the validation of a technique, because it provides information about the extent to which the method actually measures the intended outcome (in this case DNA repair activity). Several studies have performed various assays in parallel, but 
465 the correlations between the outputs of these assays are rarely described. In this section, we 466 describe the various comparisons that have been investigated to date.

467 A few reports compared data from the comet-based cellular repair assay against plasmid468 based repair assays to study BER. Astley et al. (2002) observed an increase in the removal of $469 \mathrm{H}_{2} \mathrm{O}_{2}$-induced SBs in carotenoid-supplemented Molt-17 cells by the cellular repair assay, but 470 were unable to confirm these data by means of DNA repair patch plasmid synthesis assays $471 \quad[56]$.

472 Incubation of $\mathrm{H}_{2} \mathrm{O}_{2}$-treated HeLa and Caco-2 cells with $\beta$-cryptoxanthin, a common carotenoid, 473 led to a $\sim 2$-fold increase in the rate of removal of oxidised purines by BER in the cellular repair 474 assay. This effect was confirmed with the in vitro BER assay; incision activity was about twice 475 as high with the extract prepared from carotenoid pre-incubated cells [57]. Ramos et al. (2010) 476 showed that water extracts from the Salvia species Salvia officinalis and Salvia fruticose, and 477 the polyphenolic compound luteolin-7-glucoside increased the rate of $\mathrm{H}_{2} \mathrm{O}_{2}$-induced DNA SB 478 removal in Caco-2 cells [58]. Similarly, pre-incubation for $24 \mathrm{~h}$ with extracts of Salvia Officinalis 479 and luteolin-7-glucoside increased BER-related incision activity in Caco-2 cells. The same group 480 observed the triterpenoid ursolic acid and the flavonoid luteolin (two compounds present in 481 fruits and vegetables) to enhance the $\mathrm{H}_{2} \mathrm{O}_{2}$-induced $\mathrm{SBs}$ removal rate and BER-related incision 482 activity in pre-treated Caco-2 cells [59].

483 Although BER has been studied the most, several studies also use the in vitro DNA repair assay 484 to study NER in humans [31, 32, 35, 36, 60-62], as well as in cell lines [63, 64], and in animal 485 models $[65,66]$. However, as far as we know, only one study reported a correlation of the in 486 vitro NER assay with another functional DNA repair method, i.e. BPDE-DNA adduct removal 487 over 48 hours as determined by ${ }^{32}$ P-post-labelling [31]. The slopes of the BPDE-DNA adduct 488 removal curves, were plotted against the DNA incision activity values as measured by the in vitro NER assay on substrates containing BPDE-DNA lesions, and showed a significant positive correlation between the two assays (linear regression: $\mathrm{R}^{2}=0.76$ ).

Although NER can act as a back-up mechanism for BER in situations of massive oxidative stress paired with high levels of damaged DNA [67-69], these two repair mechanisms are not always affected in the same way by external factors or disease conditions. In a study of seventy patients with sporadic colorectal cancer, BER and NER activities showed a significant positive correlation in healthy colon epithelium (Pearson test: $\mathrm{R}=0.32$ ) [35]. In contrast, Gaivao et al. (2009) did not observe a statistically significant correlation between BER and NER activity in lymphocytes of healthy volunteers [32]. Still, a direct comparison of NER and BER activity is not 
necessarily informative, because they recognize and repair different types of DNA lesions. In some cases, NER and BER can even be modulated in opposite directions. For instance, Brevik et al. (2011) observed that BER and NER activities were affected in the opposite way by kiwi fruit and phytochemical consumption (i.e. high intake of a variety of antioxidant-rich plant products) [62]. In addition, storage of blood samples at room temperature for $24 \mathrm{~h}$ reduced NER activity as assessed by the aphidicolin-block cellular repair assay for NER compared to fresh samples, whereas OGG1 activity (representing BER) was higher after 24h storage at room temperature versus freshly isolated samples [50].

Overall, both the cellular repair assay and in vitro repair assays have proven to be useful and sensitive for studying the modulation of DNA repair by nutritional factors, environmental exposures and disease state (also see section 4). We are convinced that new comet-based repair assays to study additional repair pathways are bound to come in the near future. It will be of utmost importance to include comparisons with available functional DNA repair assays into their validation process.

\section{Inter- and intra-individual variation in DNA repair activity} Variations in DNA repair activity at the level of the individual are poorly investigated. However, it is important to understand the sources of variation. There is currently insufficient knowledge to conclude to what extent the repair activity of an individual is determined by genetics, or whether it can be influenced by environmental factors. Moreover, variation between individuals in both BER and NER activities cannot be explained.

519 Gaivao et al. measured DNA repair activity on several occasions in the course of a nutritional 520 intervention study, involving 30 healthy subjects [32]. Both BER and NER were assessed by 521 applying the in vitro repair assay. As the intervention appeared to have no effect on the DNA 522 repair activity, data from the six blood samplings - at 4-week intervals - were used to examine 523 both inter- and intra-individual variation. In Table 2, the correlation coefficients for all 524 timepoint comparisons are shown, for both BER and NER separately. In 9 of the 15 525 comparisons of BER rates, the correlation was statistically significant, and this was true for 12 out of 15 comparisons of NER rates. It is interesting that the correlation coefficients did not decrease as the time between samplings increased. Thus, although there may be unknown factors that affect repair activity from time to time, there is an underlying consistency, in both BER and NER, for a given individual. While there was considerable inter-individual variation in 
531 respectively), the range between highest and lowest activity was substantially higher for NER.

532 Figure 3 shows, as examples, two of the timepoint comparisons for BER and NER. Although it 533 illustrates the relative consistancy of repair rates for individuals, the figure also shows the 534 variety of repair rates between individuals. For BER, most subjects have rates within a 3-fold 535 range; for NER (using UV-exposed substrates in the repair assay), the range is about 7-fold. 536 This is in line with a previously reported 10-fold difference in NER activity using BPDE-exposed 537 substrates in the repair assay [31]. Interestingly both studies [31, 32], reported that some 538 individuals seem to have negligible repair activity. Whether this has any health implications is 539 unclear. It is possible that a low NER rate indicates a reduced intrinsic capacity to deal with UV540 induced cyclobutane pyrimidine dimers or bulky adducts, or it could be that individuals with 541 low measured NER activities are not exposed to DNA damage and therefore their repair 542 enzymes are simply not induced.

543 Similarly, in a group of 122 subjects (mean age 24.5 y, range 19-48 y, 39 men and 83 women), 544 inter-individual variation in NER activity assessed by the aphidicolin-block cellular repair assay 545 in response to BPDE, ranged from 0.66 to $26.14 \%$ DNA in tail (mean $7.38+/-4.99 \%$ ), showing 546 an almost 40-fold difference across the group [51].

547 There are some other publications comparing repair rates between individuals using different 548 techniques (Table 3). These studies highlight considerable inter-individual variability in the 549 capacity to repair DNA. Certain factors, such as age and sex, might affect repair activity and 550 recognising such factors would be necessary for the design of human studies and 551 interpretation of repair data from such a trial. The following sections therefore describe which 552 factors, whether host factors (e.g., age, sex and genetic polymorphisms in DNA repair genes) 553 or environmental/lifestyle factors (i.e., smoking, status, diet and health status), may contribute significantly to this variability.

\subsection{Host factors}

557 Age and sex:

558 Numerous studies have reported a strong positive link between increasing age, DNA damage and defective repair [40, 41, 74-81]. However, to date few human biomonitoring studies using the comet assay have established the relationship between aging and repair activity (table 4). In one study of 375 participants with occupational exposure to asbestos, stone wool and glass fibre, increasing age was associated with increasing DNA BER activity measured by the in vitro DNA repair assay using Ro19-8022 with light to induce damage in substrate cells (Correlation 
coefficient $R=0.1$ ) [69]. In contrast, in a study of 244 men and women (mean age 41.3), neither

565 BER of oxidative damage (in vitro repair assay) nor irradiation-induced repair (cellular comet 566 assay) was affected by either age or sex [83]. A cross-sectional study of subjects from Denmark 567 showed an inverse association between age (18 to 83 years) and BER activity (using $\mathrm{KBrO}_{3}$ 568 treated cells as substrate) in PBMCs; the effect was stronger in women as compared to men 569 [30]. However, in a study specifically designed to assess the impact of age on DNA repair 570 activity, Humphreys et al., investigated the relationship between age and BER activity measured by the in vitro repair comet assay using Ro19-8022 + light damaged substrate cells [82]. BER was investigated in 3 groups of subjects of increasing age [20-35 y $(n-40), 63-70$ y $(n=35)$ and $75-82$ y $(n=22)]$. Here, the authors found a positive but weak correlation between age and BER rate $(r=0.25)$. However, it should be mentioned that the authors of this paper state that the inclusion criteria were "relaxed" for the oldest group. Consequently, subjects with disease in the oldest group might have biased the results. DNA repair activity was the same in both sexes.

The relationship between age and DNA repair may be further complicated by differences in repair activity in different strata of population studies defined by sex or race. Trzeciak et al.

580 (2008) used a cellular repair assay to study the impact of these factors on repair of $\gamma$-radiation581 induced DNA damage in PBMCs from four age-matched groups of male and female whites and 582 African-Americans between ages 30 and 64 [84]. They reported a positive association between repair activity and age in white females, but a statistically non-significant decrease in AfricanAmerican females.

Overall, the available data suggest that, while sex is not a major contributor to inter-individual variation in repair activity, age is a factor that should be taken into account (for example, by ensuring a similar age distribution in control and test groups) - though as yet there is no indication of a major positive or negative effect. Also animal studies have reported conflicting results. There are recent reports that the effect of age on BER activity (in vitro repair assay) can be tissue dependent and that the brain seems to be the most vulnerable for a decline in BER activity with age [40-42, 74]. Future human biomonitoring studies should consider studying DNA repair in other available tissues with different cell turnover, in comparison with blood cells (e.g. buccal cells, saliva, colon biopsies, etc.). The effect of race on repair activity and its interaction with age is unclear. 
597 Data from human biomonitoring studies, using the comet assay to assess the associations 598 between genetic variations in DNA repair genes and repair activity are scarce. Vodicka et al. 599 performed a relatively large-scale study [244 healthy subjects, 183 men and 61 women, mean 600 age $41 \pm 11 \mathrm{y}$ ], specifically designed to investigate the impact of various genotypes (XRCC1, 601 APE1, hOGG1, XPD, XPG, XPC, XRCC3 and NBS1) on NER and BER activities. BER (in vitro DNA repair assay) was significantly lower in people homozygous for the GG variant of hOGG1 compared with carriers of the normal genotype [83]. The ability to repair $\gamma$-irradiation damage (cellular repair assay) was significantly lower in individuals homozygous for the XRCC1 AG genotype. However, in a study by Jensen et al., healthy subjects did not show any difference in BER activity (in vitro repair assay using Ro19-8022 + light as substrate) associated with the hOGG1 Ser326Cys polymorphism; 49 subjects of each genotype were selected and groupmatched from a cross-sectional study of 1019 subjects [85]. Interestingly, there are indications for an interplay between BER and NER, or NER playing a role as a back-up mechanism for BER. For instance, a study on occupational exposure to potential genotoxic agents, observed BER activity (using the in vitro DNA repair assay) to be significantly higher in subjects carrying the XPA AA normal genotype compared to the AG and GG variants [69]. In addition a few studies have investigated the gene-environment interactions. In a study of 36 volunteers recruited to explore the impact of nutrient/gene interactions on NER activity (in vitro DNA repair assay using BPDE-DNA as substrate), subjects were grouped according to genetic polymorphisms in several NER genes (XPA, XPC, ERCC1, ERCC2, ERCC5, ERCC6, and RAD23B; [60]). Here, NER activity was significantly lower in subjects who carried a relatively large number of "low" NER activity alleles. The XPA G23A gene was the strongest predictor for NER activity, with individuals homozygous for the recessive AA variant of the gene demonstrating 3-fold lower repair activity compared to the normal genotype. Interestingly, this same XPA 23A allele was observed to be associated with lower BER activity (in vitro DNA repair assay) in colonic tumour tissues, but not in the adjacent healthy tissue [36]. A recent study investigated the impact of genetic polymorphisms on BER repair activity in 43 patients with recurrent depression disorders and 59 controls without disease [86]. The study included 12 polymorphisms in 4 key BER genes (hOGG1, MUTYH, PARP1, and LIG3), which were linked to the cellular repair activity on $\mathrm{H}_{2} \mathrm{O}_{2}$-induced $\mathrm{SBs}$, but it should be noted that the sample size reported here is small for a study investigating the influence of genotype on disease risk. 
631 Although, a meta-analysis (evaluating 38 studies) indicated higher levels of DNA damage in 632 smokers versus non-smokers [87], information on the effect of cigarette smoking on DNA 633 repair activity is conflicting. SB re-ligation activity in leukocytes following $\gamma$-irradiation (10 Gy) 634 (using the cellular repair assay), was higher in current cigarette smokers ( $n=17)$, compared with non or ex-smokers $(n=23)$ [88]. Similarly, SB re-ligation activity following exposure to $\gamma$ irradiation (5 Gy) was elevated in smokers ( $n=80,1.05 \pm 0.81 \mathrm{SSB} / 10^{9} \mathrm{Da}$ ) compared with nonsmokers ( $n=134,0.77 \pm 0.62 \mathrm{SSB} / 10^{9} \mathrm{Da}$ ) [83]. However, in this study, BER (in vitro repair assay) was not affected by smoking. BER measured using the in vitro DNA repair assay was significantly lower in poorly nourished male smokers ( $n=46$, mean age 39 y) compared to wellnourished males and females ( $n=39$, mean age $27 \mathrm{y}$ ), with mean incision activity 65.9 AU (95\% $\mathrm{Cl} 60.4,70.0)$ in smokers compared with $86.1 \mathrm{AU}(95 \% \mathrm{Cl} 76.2,99.9)$ in healthy subjects. Moreover, repair data from the cigarette smokers were substantially less variable within the group when compared with the non-smoking participants (range 30-100 AU and 10 -180 AU in the smoking versus the non-smoking subjects respectively). The same authors also studied the effect of smoking in a cohort of workers in a tire plant by performing the cellular repair assay and the in vitro BER assay [89]. Higher rates of repair of irradiation-induced DNA damage were detected in smokers versus nonsmokers, but this was not confirmed by the in vitro BER assay with Ro19-8022+light generated substrate.

Dietary factors

651 The comet assay has been used widely in human biomonitoring to assess both the impact of 652 whole foods (e.g. fruits and vegetables) and specific nutrients (phytophenols, antioxidants and 653 folic acid) on genomic instability, particularly the impact of diet on DNA SSBs and altered DNA bases (e.g. oxidative, alkylation and misincorporated uracil). In addition, several studies have described how nutrition modifies DNA repair activity (Table 5).

After the in vitro DNA repair assay came into use in 2001, several researchers started performing it in parallel to the cellular repair assay. Cellular extracts from human lymphocytes showed a markedly higher DNA repair incision activity after a single oral dose of $100 \mathrm{mg}$ CoQ10/day for 1 week compared to controls ( 3-fold increase in CoQ10 group) as detected by the in vitro BER assay [92]. Similarly, the cellular repair assay, studying the removal of Ro 198022 + light induced oxidative lesions, detected a statistically significant $\sim 2$-fold higher rate of 
663 a small randomised cross-over design study, subjects consuming between 1 and 3 kiwi fruits 664 daily for 3 weeks significantly increased in vitro BER activity (Ro19-8022+light damaged 665 substrate cells) in PBMCs from male $(n=6)$ and female $(n=8)$ healthy participants (26-54 y of 666 age) [93]. Volunteers who consumed 3 kiwi fruits each day showed a significantly elevated 667 plasma vitamin C level and substantially enhanced BER activity compared with pre668 supplementation levels (>60\%). Supplementation also increased the resistance of isolated 669 PBMCs to oxidative damage and was associated with reduced DNA SBs and oxidised base 670 damage (Fpg-sensitive sites). In contrast, there was no correlation between individual BER 671 rates and markers of DNA damage. A significant association between BER activity, assessed by 672 the in vitro DNA repair assay (Ro19-8022+ light damaged substrate cells) and antioxidant 673 status was described subsequently, with elevated plasma lutein/zeaxanthin correlating with 674 high BER activity [82]. Supplementation with carotenoids for three weeks, showed enhanced 675 re-ligation of $\mathrm{H}_{2} \mathrm{O}_{2}$-induced $\mathrm{SBs}$ and increased DNA repair patch synthesis activity compared to 676 their initial repair activity before the 3-week intervention [94]. Similarly, supplementing male 677 smokers ( $n=46$, mean age 39) with slow release vitamin C (500 mg/day) and vitamin E (182 $678 \mathrm{mg} /$ day) was found to significantly increase BER (in vitro repair assay) by approx. $27 \%$ (95\% Cl $67912-41 \%)$ after 4 weeks [39]. Inter-individual variation in incision activity was generally 680 consistent within this group (range 30-100 AU). In contrast, feeding healthy subjects ( $n=43$ 681 men and women, mean age 27 y) $600 \mathrm{~g}$ of fruits and vegetables, or the equivalent levels of 682 antioxidant vitamins and minerals as a supplement for $24 \mathrm{~d}$, did not change BER activity 683 measured by the same group and using the same assay [39]. Inter-individual variability in 684 incision activity was substantial, ranging from less than 10 to more than $180 \mathrm{AU}$, with a mean 685 of $86.1 \mathrm{AU}(95 \% \mathrm{Cl} 76.2$ - 99.9).

In a more recent study, feeding male smokers (45-75 y) a diet high in antioxidant-rich fruits and vegetables $(n=33)$ or 3 kiwifruits per day $(n=33)$ for 8 weeks significantly increased total antioxidant levels (2-fold), plasma vitamin C, $\beta$-carotene and tocopherol, compared to the control group $(n=34)$. Also BER activity was increased $40 \%(n=23)$ and $29 \%(n=25)$ upon antioxidant-rich fruits/vegetable or kiwi consumption, respectively) (measured using the in vitro DNA repair assay) [62]. Surprisingly, NER activity (in vitro repair assay and UVC radiation for substrate), was significantly decreased $(39 \%(n=13)$ and $38 \%(n=11)$; upon antioxidant-rich fruits/vegetable or kiwi consumption, respectively). In contrast, feeding young male smokers steamed broccoli (250mg/day for 10 days) did not alter BER activity (in vitro repair assay; [91]). A similar lack of effect of antioxidant supplementation on BER (in vitro repair assay) has also been described in 48 young healthy volunteers given $100 \mu \mathrm{g}$ selenium, $450 \mu \mathrm{g}$ vitamin A, $90 \mathrm{mg}$ 
vitamin C and $30 \mathrm{mg}$ vitamin E supplements for 6 weeks [71]. Inter-individual BER activity was substantially different between the volunteers (41-fold). NER (using the in vitro repair assay with BPDE-DNA as substrate) was also found to be unaffected by supplementing healthy participants (114 female and 54 male subjects aged between 18 and 45 y) flavonoid-rich blueberry and apple juice (1L/day) for 4 weeks [60]. In this study inter-individual variation, while considerable, was maintained across the two sampling periods (correlation: $R=0.69$ ).

While the majority of studies report the impact of food or supplements rich in dietary antioxidants on DNA repair activity, a few studies have investigated the impact of other key dietary agents. Low intake of folate is associated with an increased risk of several human cancers, particularly colon cancer [95]. Numerous studies have reported that folate deficiency induces genomic instability and malignant transformation in vitro, in animals and in human studies [95]. In a relatively large-scale, randomised double blind-placebo controlled intervention study, participants ( $\mathrm{n}=61,20-60$ y of age, male and female non-smokers and nonsupplement users) were given $1.2 \mathrm{mg}$ folic acid daily for 12 weeks to investigate whether enhancing folate status could improve markers of genomic stability, including BER incision activity measured using the in vitro DNA repair assay [90]. BER incision activity was similar across both intervention groups prior to supplementation, with a median value in both treatment groups of $63 \mathrm{AU}$, extending from 34 and $93 \mathrm{AU}$ (2.5 fold range). While there was no association between red cell folate status and BER activity at the start of the study, increasing folate intake resulted in significantly decreased BER in those volunteers with the lowest preintervention folate levels, indicating that BER can be modulated by folate status.

These studies highlight that diet (and supplement use), has a significant influence on DNA repair activity. The impact of other common nutrients and non-nutrients (such as alcohol and caffeine), as well as other lifestyle factors (including physical activity) on inter-individual variation in DNA repair activity measured using the comet assay remains largely unknown and therefore deserves further attention.

Health status

The comet assay has been used widely to determine the relationship between DNA damage (as a marker of genome instability) and various diseases including cancer, vascular disease, diabetes and inflammation. [96] [97] [98] [99]. However, only a few studies to date have investigated the impact of health status (particularly malignant transformation) on NER activity using the comet assay. 
Palyvoda et al., measured NER repair of $\gamma$-radiation-induced (2 Gy) DNA SBs in lymphocytes isolated from 44 healthy donors and 38 patients with squamous cell carcinoma of the head and neck (SCCHN), prior to treatment [100]. The cellular repair assay, following a time course of repair post-irradiation (0-180 $\mathrm{min}$ ), was used to measure endogenous DNA SBs, radiationinduced damage, rate of repair and residual or non-repaired damage in isolated lymphocytes cultured for $24 \mathrm{~h}$ prior to treatment. Endogenous DNA SBs was almost 3-fold higher in patients with SCCHN compared with healthy subjects (median 90.3 vs 33.3 AU respectively), with significantly more individuals in the cancer group showing a high level of damage. Overall, NER repair rates were not significantly different between participants with and without cancer, due to substantial variation in measured repair activity across all individuals. However, by stratifying individuals into subjects with high endogenous DNA SBs, high induced DNA damage, low NER rate and high residual DNA damage, a significantly higher proportion of cancer cases displayed this "negative phenotype" compared with healthy participants (39.4\% vs. $7.3 \%$ respectively). The variation in DNA damage and repair in this study was substantial, making it difficult to draw strong conclusions. It is also important to note that cases and controls were not matched in this study, and that age, sex and cigarette smoking status were markedly different between the two groups. A significant association between cancer incidence and low NER rate was observed in a smaller study of SCCHN cases $(n=12)$ and healthy donors $(n=15)$, in this case matched for age, sex and cigarette smoking [88]. Whole blood was used to measure DNA damage and repair following $\gamma$-irradiation (10Gy) using the cellular comet assay, without pre-culture, and assessing percentage tail DNA using computerised image analysis. Here, DNA repair activity was significantly lower in patients with SCCHN cancers relative to controls (46.5\% v $36.8 \%$ respectively).

How other human pathologies and effectors of health and disease, such as low-grade sustained inflammation [101], affect individual variation in DNA repair activity is essentially unidentified and represents a substantial gap in knowledge. In any case, the studies so far reported, have been case-control studies and it is not possible to discern whether a difference in repair activity is a cause or an effect of the disease (or possibly an effect of treatment). What is really needed is a prospective study, i.e. a large cohort of healthy subjects whose repair activities are measured and who are then followed up for a long enough period of time for disease to develop and be recorded.

\subsection{General comment on individual variation in DNA repair}


763 The studies reviewed above show that age, sex, health status, diet, and other lifestyle factors

764 such as smoking, impact to some extent on DNA repair (BER and NER) activity and contribute

765 substantially to the significant inter-individual variation in repair rates described in numerous human studies. It should also be noted that large assay variation may be interpreted wrongly as inter-individual or intra-individual variation. However, if intra-individual variation (estimated from repeat measurements on different occasions) appears to be at a low level, assay variation can be discounted. There is a need for controlled studies that systematically assess inter-, intra- individual and assay variation in for instance ring-trials. One approach would be similar to the ECVAG ring trials on DNA damage endpoints, in which contributors to the overall variation were assessed in a systematic manner [102-105].

Host factors such as age and sex, and certain anthropometric characteristics such as body mass index can be relatively easily dealt with by carefully matching control and test groups. Adjusting for other factors, such as single nucleotide polymorphisms in DNA repair genes is more difficult, principally due to the requirement for substantially larger numbers of participants to adequately power these biomonitoring studies. Genetic variation in DNA repair genes can also be included in intervention studies as effect modifiers [60]. While specific dietary items obviously have an effect on repair activity, as discussed above and reviewed before [106], it is difficult due to lack of information to estimate the impact of other lifestyle factors such as physical activity, sunlight exposure, drug use and health status on interindividual variation in DNA repair activity. The advantage of studying DNA repair as phenotypic marker rather than single nucleotide polymorphisms or gene expression is that the latter do not take into account epigenetic and post-transcriptional modifications that can affect the final DNA repair activity.

\section{Repair activity kinetics and timing}

No studies have specifically assessed DNA repair kinetics in a time-course investigation in humans, using multiple sampling over a short period of time. Assessing DNA repair kinetics is important for selecting optimal sampling times relative to exposure. For instance, if exposure to DNA damaging compounds induces DNA repair, a measurement shortly after exposure will indicate higher levels of repair. On the other hand, after a longer period of time when damage has again decreased due to DNA repair or cell death, such an increase in DNA repair activity may no longer be detectable. Unfortunately, most of the information on DNA repair kinetics 
in samples that have been obtained at a single time-point before, during or after a change in exposure.

798 Only one study has investigated the effect of short-term phytochemical supplementation on repair activity. Intake of green tea was associated with increased BER activity in lymphocytes 800 that were obtained 60 and 120 min after drinking $200 \mathrm{~mL}$ of freshly prepared tea [107]. 801 Although this study suggests that changes in DNA repair activity after a particular exposure can be very quick (minutes to hours), most studies that investigated dietary interventions actually studied the changes over a period of several days to weeks (see paragraph 4.2). Regarding green tea consumption, 12 weeks of regular green tea consumption indeed significantly increased in vitro BER activity toward Ro19-8022 + light generated DNA damage in lymphocytes [108], but the study by Ho et al. (2014) [107] suggests that this change could already have been detected at much earlier time points. Time points chosen for sampling in other dietary interventions with in vitro BER or NER activity as endpoint vary between 1 to 8 weeks [92, 62, 71, 93], with reported washout periods between 1 and 2 weeks [92, 93]. Interpretation may become more complex if the intervention is performed in smoking individuals, because smoking by itself may already affect BER or NER activity [39, 91] (see paragraph 4.2).

813 It is a matter of debate how the activity of hOGG1 in human cells is regulated, as the OGG1 814 gene may be constitutively expressed [28]. Presence of DNA damage seems logical as an 815 inducer of DNA repair. Indeed, animal studies show that DNA repair can be induced by specific 816 DNA damaging triggers and that alterations in repair activity are relatively quick (within days) 817 [65]. In in vitro studies with cell lines, induction of BER or NER can occur within hours [58, 59, $101,109]$. The number of investigations in which changes in DNA repair were studied after a specific exposure of humans is limited: A study with controlled exposure to wood smoke, although statistically underpowered, showed a slightly increased in vitro BER activity and increased urinary 8-oxoGua (i.e. repair product of hOGG1) at $20 \mathrm{~h}$ post-exposure [110]. Another short-term study reported increased levels of oxidatively damaged DNA and unaltered BER activity in PBMCs after 6 or $24 \mathrm{~h}$ controlled exposure to traffic-related air pollution [111]. Likewise, oral exposure to nanomaterials showed increased levels of oxidatively damaged DNA in the liver of rats at $24 \mathrm{~h}$ post-exposure, whereas the in vitro BER activity to Ro19-8022 + light generated DNA substrate cells was unaltered [112].

827 To summarise, BER and NER kinetics have not been well investigated in humans and animals.

828 There are inconsistent reports of altered BER activity after dietary interventions and particle 829 exposure, but sampling times are not frequent enough to draw any conclusions on the time 
830 frame in which the changes occur. There are currently too few studies on NER activity to 831 speculate about timing of sampling for assessment of changes in repair activity. From the 832 available literature, it is not possible to suggest an optimal time of sampling in relation to 833 exposure for the assessment of BER and NER activity. Therefore, to improve the applicability of 834 DNA repair measurements in human biomonitoring, it is essential to perform studies in which repair activity is assessed at various time points after exposure/ intervention.

\section{Surrogate vs. target tissues}

PBMCs (frequently referred to as lymphocytes) are extensively used to measure DNA repair activity in human biomonitoring studies. They circulate through the whole body and are regarded as sentinel cells since they can have a relatively long life-span [113]. Moreover, they are easily obtained, available in large numbers and easy to handle and culture if necessary. The purity of the cells fraction is normally not specified and a mixture is probably the most commonly used material. While they are convenient as surrogate cells, circulating blood cells are not the target for carcinogenesis, and the response of these cell types does not necessarily mimic the effect in true target tissue cells. Also, confounding factors (e.g., smoking, diet, medication, air pollution, exercise) should be taken into account [33, 114], because the reaction of surrogate cells in the exposure-outcome relationship may be different in target organ cells. However, using white blood cells is relatively non-invasive and they are the surrogate cells of choice in studies where (as is usually the case) the target tissue is not readily attainable [115].

851 There are only 3 studies with humans in which tissues other than lymphocytes or PBMCs have 852 been used to measure DNA repair activity by the comet assay [33, 35, 36]. In these studies, 853 DNA repair activity was measured in colon biopsies and two of these assessed the correlation 854 between DNA repair activity in tissues and PBMCs.

855 Herrera et al. observed that DNA cross-link repair activities of colon tumour epithelial cells and 856 lymphocytes from colon cancer patients (using the in vitro repair assay) were not correlated. 857 Thus, lymphocytes were not predictive for the repair ability of the tumour [33]. Slyskova et al. 858 found a positive correlation in BER and NER activity between PBMCs and healthy colon tissues, 859 but not between PBMCs and colon tumour tissues [35]. More studies are needed to draw 860 conclusions about the suitability of using lymphocytes or PBMCs to reflect the DNA repair 861 activity of healthy target organs. However, studies in which biopsies of organs from healthy people are included are difficult to perform. 
863 Epithelial cells, as specialized components of many organs, have the potential of being an 864 attractive bio-matrix to evaluate the DNA repair activity of individuals. Examples of possible 865 sources of exfoliated epithelial cells in human biomonitoring studies are presented in Table 6. 866 Unfortunately, although there are many studies that use the comet assay to measure DNA 867 damage in buccal, nasal, tear duct, lens and corneal epithelial cells [116], DNA repair activity 868 has never been explored in these biological matrices using the comet assay. Most of these cell 869 types, while not necessarily target cells for carcinogenesis, have the distinct feature of coming 870 into direct contact with various environmental xenobiotics, and so they should provide useful 871 information on the initial response of cells to exposure. Another characteristic of most of the 872 cell types is that they have a rapid turnover; therefore they would only reflect recent events 873 that affected DNA repair. Future studies are needed, addressing the quality and quantity of 874 exfoliated cells that need to be obtained in order to apply the in vitro repair assays. Cell 875 recovery should be high enough to make extracts of sufficient volume and protein 876 concentration to apply to substrate cells. Cell counts may be insufficient for buccal cells 877 obtained by mouth rinsing or cheek scrapings (unpublished data). Cell counts are in theory 878 sufficiently high for epithelial cells in urine [117]. Broncho-alveolar lavages [118] and induced 879 sputum [119] also produce a sufficient number of cells, but these are predominantly 880 leukocytes. It should also be noted that repair activity measurements in lavages from the 881 airways are complicated by the fact that respirable toxicants can induce the influx of cells from 882 the blood and the composition of cells in the broncho-alveolar lavage fluid is dependent on the 883 type and stage of pulmonary inflammation. The applicability of epithelial cells for the repair 884 assays needs to be established, as a large proportion of the exfoliated cells may be dead. For 885 small (needle) biopsies an amount of approx. $5 \mathrm{mg}$ of tissue should be enough to make protein extracts [38].

887

\section{Discussion and conclusion}

889

The comet assay and its modifications to measure DNA repair activity are frequently used in human biomonitoring studies. However, for the correct interpretation of the data of such biomonitoring studies, validation studies are needed that have to date not been performed in a systematic way. In this manuscript, we have compiled the information that is needed for the validation of the DNA repair comet assays, including intra- and inter-Individual variation, repair kinetics, the use of surrogate tissues, and comparison with other methods. 
The intra-individual variation over a relatively short period of time (weeks to several months) was reported to be small for both NER and BER, because measurements in the same individuals at two different moments correlated significantly and the slope of the regression line was close to 1.0. This indicates that the measurement of DNA repair activity reflects an individual's intrinsic repair activity.

How a low DNA repair activity should be interpreted is an open question; a person can have a low repair activity and may thus have a higher cancer risk, but it is also possible that low DNA repair activity simply reflects the absence of exposure, and thus DNA repair is not needed. Therefore, for proper interpretation of DNA repair activity data, a combined analysis with exposure data and/or other biomarkers (particularly DNA damage) is required.

It is important to understand the kinetics of DNA repair after exposure. If DNA repair is measured shortly after a DNA damaging exposure, DNA repair may still be induced. On the other hand, when repair activity is assessed at a later time point relative to the exposure, DNA damage may already be removed and repair is no longer needed. Knowledge about the inducibility of DNA repair is therefore indispensable.

The literature is equivocal about the regulation of BER, but NER is likely to be inducible. The different DNA repair pathways are likely to have different modes of regulation. BER often deals with DNA damage induced by endogenously produced DNA reactive compounds. For instance, reactive oxygen species are continuously present (and needed) in the body, but can also lead to oxidised DNA bases. Therefore, these oxidised DNA bases can be considered as physiological DNA lesions and the enzymes involved in BER are thus assumed to be in some way constitutive. In contrast, NER most often deals with damage caused by exogenous agents (i.e., chemicals and radiation), so the enzymes involved in this pathway are probably only synthesized when needed in episodes of increased exposure.

This inducibility of NER may also be reflected in the inter-individual variation that is observed in the general population, because the inter-individual variation in NER is reportedly higher than the variation in BER. The inducibility of NER may be related to lifestyle factors in combination with the genetic background. Surprisingly, some healthy subjects seem to have undetectable levels of NER when using comet assay approaches, which could reflect a lack of exposure or a limitation of the comet assay approach. This observation therefore needs confirmation by using other assays. For interpreting NER data, we therefore suggest that these should always be combined with exposure data. 
Although the literature suggests that BER activity is less inducible, some studies showed that dietary interventions may still increase BER activity. Induction of repair activity can, of course, occur post-translationally as well as at the level of transcriptional regulation. Therefore, more work is needed to understand the impact of lifestyle, including genetic background, exposure and dietary habits on both BER and NER activity.

Human biomonitoring studies most of the time use leukocytes or PBMCs to assess DNA repair activity. Only a limited number of studies showed a correlation between DNA repair in PBMCs and the target tissue cells, so more work is needed to confirm that repair in blood cells actually reflects the intrinsic repair capacity of internal organs. However, the work that has been published to date looks promising. The total blood cell population (i.e., leukocytes) consists of different cell types including monocytes, lymphocytes and granulocytes. These cell types have differences in life span, concentrations in blood and most probably also different levels of DNA repair. If common diseases, such as a simple cold, affect blood composition, this could change the repair activity that is measured when using total WBC. In that case, differences in DNA repair activity between or within individuals could be related to the percentages of the different cell types in the blood sample. One should keep in mind that isolating blood cell subpopulations automatically requires more work and hands-on time when preparing the samples and this may not always be feasible in large scale biomonitoring studies. Therefore, a more thorough understanding of DNA repair in blood cell subpopulations may guide the decision to use total white blood cells, isolated PBMCs or PBMC subpopulations in human 947 biomonitoring studies.

948 It is worth to mention that conflicting results observed in some of the studies summarised in 949 this review can be due to the small sample size. However, these studies often show biologically relevant effects and can give important information for larger future studies. More studies with higher samples size are needed.

However, in order to analyze large numbers of samples in a limited amount of time, as is often the case in human biomonitoring, there is a need to develop high throughput approaches; for instance the CometChip is an approach to be explored [120]. Even if the number of samples per run is increased, samples may still be analysed in batches. To avoid batch differences, the comet assay should be further optimized by, for instance, standardizing the preparation of substrate cells, including positive and negative controls, and using assay controls. Although the COST-Action hCOMET (CA15132) may address some of these issues, it will need concerted action by the comet assay community to carry out a full technical and field validation of the 
repair comet assay, to reduce inter-assay and inter-laboratory variations, and to ensure the proper comparison and interpretation of results of biomonitoring studies.

\section{Acknowledgments}

We thank the hCOMET project (COST Action, CA 15132) for support. A.A. thanks the Ministry of Economy, Industry and Competitiveness ('Ramón y Cajal' programme, RYC2013-14370) of the Spanish Government for personal support.

\section{Funding}

This research did not receive any specific grant from funding agencies in the public, commercial, or not-for-profit sectors.

\section{References}

[1] E.C. Friedberg, G.C. Walker, W. Siede, R.D. Wood, R.A. Schultz, T. Ellenberger, Correcting altered bases in DNA: DNA repair, in: E.C. Friedberg, G.C. Walker, W. Siede, R.D. Wood, R.A. Schultz, T. Ellenberger (Eds.), DNA Repair and Mutagenesis, ASMPress, Washington DC, 2006, pp. $107-460$.

[2] S.A.S Langie, G. Koppen, D. Desaulniers, F. Al-Mulla, R. Al-Temaimi, A. Amedei, A. Azqueta, W.B. Bisson, D. Brown, G. Brunborg, A.K. Charles, T. Chen, A. Colacci, F. Darroudi, S. Forte, L. Gonzalez, R.A. Hamid, L.E. Knudsen, L. Leyns, A. Lopez de Cerain, L. Memeo, C. Mondello, C. Mothersill, A.-K. Olsen, S. Pavanello, J. Raju, E. Rojas, R. Roy, E. Ryan, P. Ostrosky-Wegman, H.K. Salem, I. Scovassi, N. Singh, M. Vaccari, F.J. Van Schooten, M. Valverde, J. Woodrick, L. Zhang, N. van Larebeke, M. Kirsch-Volders, A.R. Collins, Causes of genome Instability: the effect of low doses chemicals exposures in modern society, Carcinogenesis 36 (2015) 61-88.

[3] A. Azqueta, J. Slyskova, S.A.S. Langie, I.O. Gaivão, A.R. Collins, Comet assay to measure DNA repair: approach and applications, Front. Genet. 5 (2014) 288.

[4] N. Chatterjee, G.C. Walker, Mechanisms of DNA Damage, Repair, and Mutagenesis, Environ. Mol. Mut. 58 (2017) 235-263.

[5] G. Koppen, A. Azqueta, B. Pourrut, G. Brunborg, A.R. Collins, S.A.S. Langie, The nest three decades of the comet assay: a report of the $11^{\text {th }}$ International Comet Assay Workshop, Mutagenesis 32 (2017) 397-408.

[6] A.R. Collins, A. Azqueta A, Single cell gel electrophoresis combined with lesion-specific enzymes to measure oxidative damage to DNA, Methods Cell Biol. 112 (2012) 69-92.

[7] P.R. Cook, I.A. Brazell, E. Jost, Characterization of nuclear structures containing superhelical DNA, J. Cell Sci. 22 (1976) 303-324.

[8] A.R. Collins, A. Dusinska, M. Franklin, M. Somorovska, H. Petrovska, S. Duthie, L. Fillion, M. Panaviotidis, K. Raslova, N, Vaughan, Comet assay in human biomonitoring studies: reliability, validation, and applications, Environ. Mol. Mutagen. 30 (1997) 139-146. 
[9] A. Azqueta, S. Meier, C. Priestley, K.B. Gutzkow, G. Brunborg, J. Sallette, F. Soussaline, A.R. 999 Collins, The influence of scoring methods on variability in results obtained with the comet 1000 assay, Mutagenesis 26 (2011) 393-399.

1001 [10] A. Azqueta, A.R. Collins, The essential comet assay: A comprehensive guide to measuring 1002 DNA damage and repair, Arch. Toxicol. 87 (2013) 949-968.

1003 [11] N.P. Singh, M.T. McCoy, R.R. Tice, E.L. Schneider, A simple technique for quantitation of 1004 low levels of DNA damage in individual cells, Exp. Cell Res. 175 (1988) 184-191.

1005 [12] A.R. Collins, A. Azqueta, DNA repair as a biomarker in human biomonitoring studies; 1006 further applications of the comet assay. Mutat. Res. 736 (2012) 122-129.

1007 [13] A.R. Collins, M.J. Ord, R.T. Johnson, Correlations of DNA damage and repair with nuclear 1008 and chromosomal damage in HeLa cells caused by methylnitrosamides, Cancer Res. 41 (1981) 1009 5176-5187.

1010 [14] R. Crebelli, P. Carta, C. Andreoli, G. Aru, G. Dobrowolny, S. Rossi, A. Zijno, Biomonitoring of 1011 primary aluminium industry workers: detection of micronuclei and repairable DNA lesions by 1012 alkaline SCGE, Mutat. Res./Genet. Toxicol. Environ. Mutagen. 516 (2002) 63-70.

1013 [15] K. Vande Loock, I. Decordier, R. Ciardelli, D. Haumont, M. Kirsch-Volders, An aphidicolin1014 block nucleotide excision repair assay measuring DNA incision and repair capacity, 1015 Mutagenesis 25 (2010) 25-32.

1016 [16] A.R. Collins, A. Ma, S.J. Duthie, The kinetics of repair of oxidative DNA damage (strand 1017 breaks and oxidised pyrimidines) in human cells, Mutat. Res. 336 (1995) 69-77.

[17] M.H.L. Green, A.P.W. Waugh, J.E. Lowe, S.A. Harcourt, J. Cole, C.F. Arlett, Effect of deoxyribonucleosides on the hypersensitivity of human peripheral blood lymphocytes to UV-B and UV-C irradiation, Mutat. Res. 315 (1994) 25-32.

[18] A. Redaelli, R. Magrassi, S. Bonassi, A. Abbondandolo, G. Frosina, APendonuclease activity in humans: development of a simple assay and analysis of ten normal individuals, Teratog. Carcinog. Mutagen. 18 (1998) 17-26.

[19] R.M. Elliott, S.B. Astley, S. Southon, D.B. Archer, Measurement of cellular repair activities for oxidative DNA damage, Free Radic. Biol. Med. 28 (2000) 1438-1446.

[20] T. Roldan-Arjona, Y.F. Wei, K.C. Carter, A. Klungland, C. Anselmino, R.P. Wang, M. the antimutator enzyme 8-hydroxyguanine-DNA glycosylase, Proc. Natl. Acad. Sci. USA 94 (1997) 8016-8020. microarray for the monitoring of repair enzyme activity towarddifferent DNA base damage, Anal. Biochem. 333 (2004) 182-192. 1312-1319. damage and risk of head and neck cancer, Cancer Res. 66 (2006) 11683-11689. 
1047 [26] Y. Leitner-Dagan, Z. Sevilya, M. Pinchev, R. Kremer, D. Elinger, H.S. Rennert, E. 1048 Schechtman, L. Freedman, G. Rennert, Z. Livneh, T. Paz-Elizur, Enzymatic MPG DNA repair 1049 assays for two different oxidative DNA lesions reveal associations with increased lung cancer 1050 risk, Carcinogenesis 35 (2014) 2763-2770.

1051 [27] A.R. Collins, I.M. Fleming, C.M. Gedik, In vitro repair of oxidative and ultraviolet-induced 1052 DNA damage in supercoiled nucleoid DNA by human cell extract, Biochim. Biophys. Acta 1219 1053 (1994) 724-727.

1054 [28] A. Azqueta, J. Slyskova, S.A. Langie, I.G. O'Neill, A.R. Collins, Comet assay to measure DNA 1055 repair: approach and applications, Front. Genet. 5 (2014) 288. differences in DNA base excision repair activity measured in vitro with the comet assay, Mutagenesis 16 (2001) 297-301.

[30] M. Løhr, A. Jensen, L. Eriksen, M. Gronbaek, S. Loft, P. Møller, Association between age and repair of oxidatively damaged DNA in human peripheral blood mononuclear cells, Mutagenesis $30(2015) 695-700$. Godschalk, Development and validation of a modified comet assay to phenotypically assess nucleotide excision repair, Mutagenesis 21 (2006) 153-158. Toxicol. 25 (2009) 45-52.

[33] M. Herrera, G. Dominguez, J.M. Garcia, C. Pe na, C. Jimenez, J. Silva, V. Garcia, I. Gomez, epithelial tumor cells from colon cancer patients measured in vitro with the comet assay, Clin. Cancer Res. 15 (2009) 5466-5472. nucleotide excision repair activities in mammalian cells and tissues using the comet assay - a methodological overview, DNA repair 12 (2013b): 1007-1010. Levy, M. Schneiderova, V. Liska, L. Holubec, R. Kumar, P. Soucek, A. Naccarati, P. Vodicka. Functional, genetic, and epigenetic aspects of base and nucleotide excision repair in colorectal carcinomas, Clin. Cancer Res. 18 (2012) 5878-5887.

1079 [36] J. Slyskova, S.A.S. Langie, A.R. Collins, P. Vodicka, Functional evaluation of DNA repair in 1080 human biopsies and their relation to other cellular biomarkers, Front. Genet. 5 (2014) 116.

1081 [37] A.R. Collins, A. Azqueta A, Methods for measuring DNA repair: Introduction, and cellular 1082 repair, in: I. Gaivao, M. Sierra (Eds.), Genotoxicity and DNA repair; a practical approach, 1083 Humana Press-Springer, New York, 2014, pp. 365-376.

1084 [38] G. Speit, C. Leibiger, S. Kuehner, J. Högel, Further investigations on the modified comet 1085 assay for measuring aphidicolin-block nucleotide excision repair, Mutagenesis 28 (2013) 1451086 151. 

DNA repair phenotype and dietary antioxidant supplementation, Br. J. Nutr. 99 (2008) 10181024.

1090 [40] S.A.S. Langie, K.M. Cameron, K.J. Waldron, K.P.R. Fletcher, T. Zglinicki, J.C. Mathers, 1091 Measuring DNA repair incision activity of mouse tissue extracts towards singlet oxygen1092 induced DNA damage: a comet-based in vitro repair assay, Mutagenesis 26 (2011) 461-471.

1093 [41] J.P. Gorniak, K.M. Cameron, K.J. Waldron,T. Zglinicki, J.C. Mathers, S.A.S. Langie SAS, 1094 Tissue differences in BER-related incision activity and non-specific nuclease activity as 1095 measured by the comet assay, Mutagenesis 28 (2013) 673-81. [42] L. Mikkelsen, K. Bialkowski, L. Risom, M. Løhr, S. Loft, P. Møller, Aging and defense against generation of 8-oxo-7,8-dihydro-2'-deoxyguanosine in DNA. Free Radic Biol Med 47: 608-615, 2009.

[43] K.B. Frank, D.D. Derse, K.F. Bastow, Y.C. Cheng, Novel interaction of aphidicolin with herpes simplex virus DNA polymerase and polymerase-associated exonuclease, J. Biol. Chem. 259 (1984) 13282-13286.

[44] L.P. Goscin, J.J. Byrnes, J. J., DNA polymerase delta: one polypeptide, two activities. Biochemistry 21 (1982) 2513-2518.

[45] C.H. Cheng, R.D. Kuchta, DNA polymerase epsilon: aphidicolin inhibition and the relationship between polymerase and exonuclease activity. Biochemistry 32 (1993) 85688574.

[46] R.W.L. Godschalk, C. Ersson, P. Riso, M. Porrini, S. Langie, F.-J. van Schooten, A. Azqueta, A.R. Collins, G.D.D. Jones, R.W.L. Kwok, D.H. Phillips, O. Sozeri, A. Allione, G. Matullo, L. Möller, L. Forchhammer, S. Loft, P. Møller, DNA repair measurements using the modified comet assay: an inter-laboratory comparison within the European Comet Assay Validation Group (ECVAG), Mutagenesis 757 (2013) 60-67.

[47] A. Borghini, M. Roursgaard, M.G. Andreassi, A. Kermanizadeh, P. Møller, Repair activity of oxidatively damaged DNA and telomere length in human lung epithelial cells after exposure to multi-walled carbon nanotubes, Mutagenesis 32 (2017) 173-180.

[48] P. Møller, K. Jantzen, M. Løhr, M.H. Andersen, D.M. Jensen, M. Roursgaard, P.H. Danielsen, A. Jensen, S. Loft, Searching for assay controls for the Fpg- and hOGG1-modified comet assay, Mutagenesis 33 (2018) 9-19.

1118 [49] S. Shaposhnikov, A. Azqueta, S. Henriksson, S. Meier, I. Gaivao, N.H. Huskisson, A. Smart, G. Brunborg, M. Nilsson, A.R. Collins, Twelve-gel slide format optimised for comet assay and fluorescent in situ hybridisation, Toxicol. Lett. 195 (2010) 31-34.

[50] A. Allione, P. Porcedda, A. Russo, F. Ricceri, V. Simonelli, A. Minoprio, S. Guarrera, B. Pardini, F. Mazzei, E. Dogliotti, C. Giachino, G. Matullo, Effect of blood storage conditions on DNA repair capacity measurements in peripheral blood mononuclear cells, Mutat. Res. 749 (2013a) 73-79.

[51] A. Allione, A. Russo, F. Ricceri, K. Vande Loock, S. Guarrera, F. Voglino, M. Kirsch-Volders, G. Matullo, Validation of the nucleotide excision repair comet assay on cryopreserved PBMCs to measure inter-individual variation in DNA repair capacity, Mutagenesis 28 (2013b) 65-70. 

Ruchirawat, B.P. Enqelward, Cometchip: A high-throughput 96-well platform for measuring DNA damage in microarrayed human cells, J. Vis Exp. 92 (2014) e50607.

1133 [54] Y.W. Li, X.J. Feng, W. Du, Y. Li, B.F. Liu, Ultrahigh-throughput approach for analyzing single1134 cell genomic damage with an agarose-based microfluidic comet array, Anal Chem. 85 (2013) 1135 4066-4073.

1136 [55] Y. Qiao, C. Wang, M. Su, L. Ma, Single cell DNA damage/repair assay using halochip, Anal 1137 Chem. 84 (2012) 1112-1116.

1138 [56] S.B. Astley, R.M. Elliott, D.B. Archer, S. Southon, Increased cellular carotenoid levels 1139 reduce the persistence of DNA single-strand breaks after oxidative challenge, Nutr. Cancer 43 1140 (2002) 202-213.

[57] Y. Lorenzo, A. Azqueta, L. Luna, F. Bonilla, G. Dominguez, A.R. Collins, The carotenoid bcryptoxanthin stimulates the repair of DNA oxidation damage in addition to acting as an antioxidant in human cells, Carcinogenesis 30 (2009) 308-314.

[58] A.A. Ramos, A. Azqueta, C. Pereira-Wilson, A.R. Collins, Polyphenolic compounds from Salvia species protect cellular DNA from oxidation and stimulate DNA repair in cultured human cells, J. Agric. Food Chem. 58 (2010a) 7465-7471.

[59] A.A. Ramos, C. Pereira-Wilson, A.R. Collins, Protective effects of ursolic acid and luteolin against oxidative DNA damage include enhancement of DNA repair in Caco-2 cells, Mutat. Res. 692 (2010b) 6-11.

[60] S.A.S. Langie, L.C. Wilms, S. Hamalainen, J.C. Kleinjans, R.W. Godschalk, F.J. van Schooten, Modulation of nucleotide excision repair in human lymphocytes by genetic and dietary factors, Brit. J. Nutr. 103 (2010) 490-501.

[61] A. Brevik, I. Gaivao, T. Medin, A. Jorgenesen, A. Piasek, J. Elilasson, A. Karlsen, R. Blomhoff, T. Veggan, A.K. Duttaroy, A.R. Collins, Supplementation of a western diet with golden kiwifruits (Actinidia chinensis var.'Hort 16A':) effects on biomarkers of oxidation damage and antioxidant protection, Nutr. J. 10 (2011) 54.

[62] A. Brevik, A. Karlsen, A. Azqueta, A.E. Tirado, R. Blomhoff, A.R. Collins, Both base excision repair and nucleotide excision repair in humans are influenced by nutritional factors, Cell Biochem. Funct. 29 (2011) 36-42.

[63] S.A. Langie, A.M. Knaapen, J.M. Houben, F.C. van Kempen, J.P. de Hoon, R.W. Gottschalk, excision repair during oxidative stress, Toxicol. Lett. 168 (2007) 302-309.

[64] N. Güngör, R.W. Godschalk, D.M. Pachen, F.J. Van Schooten, A.M. Knaapen, Activated myeloperoxidase, FASEB J. 21 (2007) 2359-67.

1166 [65] S.A. Langie, P. Kowalczyk, B. Todek, R. Zabielski, T. Dziaman, R. Olinski, F.J. van Schooten, 1167 R.W. Godschalk, The effect of oxidative stress on nucleotide-excision repair in colon tissue of newborn piglets, Mutat. Res. 695 (2010) 75-80.

[66] N. Güngör, A. Haegens, A.M. Knaapen, R.W. Godschalk, R.K. Chiu, E.F. Wouters, F.J. van Schooten, Lung inflammation is associated with reduced pulmonary nucleotide excision repair in vivo, Mutagenesis 25 (2010) 77-82. 
repair in the removal of oxidatively damaged DNA bases in Saccharomyces cerevisiae, Mol. 1175 Genet. Genomics 265 (2001) 1087-1096.

1176 [68] M. D’Errico, E. Parlanti, M. Teson, B.M. de Jesus, P. Degan, A. Calcagnile, P. Jaruga, M. 1177 Bjoras, M. Crescenzi, A.M. Pedrini, J.M. Egly, G. Zambruno, M. Stefanini, M. Dizdaroglu, E. 1178 Dogliotti, New functions of XPC in the protection of human skin cells from oxidative damage, 1179 EMBO J. 25 (2006) 4305-4315.

1180 [69] M. Dusinska, Z. Dzupinkova, L. Wsolova (2006), Possible involvement of XPA in repair of 1181 oxidative DNA damage deduced from analysis of damage, repair and genotype in a human 1182 population study, Mutagenesis 21 (2006) 205-211.

1183 [70] K. Janssen, K.Schlink, W.Götte, B.Hippler, B.Kaina, F.Oesch, DNA repair activity of 81184 oxoguanine DNA glycosylase 1 (OGG1) in human lymphocytes is not dependent on genetic 1185 polymorphism Ser326/Cys326, Mutat. Res. 486 (2001) 207-216.

[71] F. Caple, E.A. Williams, A. Spiers, J. Tyson, B. Burtle, A.K. Daly, J.C. Mathers, J.E. Hesketh,. (2010) Inter-individual variation in DNA damage and base excision repair in young, healthy non-smokers: effects of dietary supplementation and genotype, Br.J.Nutr. 103 (2010) 15851593.

[72] Y. Qiao, M.R. Spitz, Z. Guo, M. Hadeyati, L. Grossman, K.H. Kraemer, Q. Wei, Rapid assessment of repair of ultraviolet DNA damage with a modified host-cell reactivation assay using a luciferase reporter gene and correlation with polymorphisms of DNA repair genes in normal human lymphocytes, Mutat. Res. 509 (2002) 165-174.

[73] J. Tyson, F.Caple, A.Spiers, B.Burtle, A.K.Daly, E.A.Williams, J.E.Hesketh, J.C. Mathers, Inter-individual variation in nucleotide excision repair in young adults: effects of age, adiposity, micronutrient supplementation and genotype, Brit. J. Nutr. 101 (2009) 1316-1323.

1197

1198

1199

[74] S.A. Langie, K.M. Cameron,G. Ficz, D. Oxley, B. Tomaszewski, J.P. Gorniak, L.M. Maas, R.W. Godschalk, F.J. van Schooten, W. Reik, T. von Zglinicki, J.C. Mathers, The Ageing Brain: Effects on DNA Repair and DNA Methylation in Mice, Genes 8 (2017)75.

1200 [75] D.C. Cabelof, J.J. Raffoul, S. Yanamadala, C. Ganir, Z. Guo, A.R. Heydari, Attenuation of 1201 1202 DNA polymerase beta-dependent base excision repair and increased DMS-induced mutagenicity in aged mice, Mutat. Res. 500 (2002) 135-145.

1203

[76] D.C. Cabelof, S. Yanamadala, J.J. Raffoul, Z. Guo, A. Soofi, A.R. Heydari, Caloric restriction promotes genomic stability by induction of base excision repair and reversal of its age-related decline, DNA Repair 2 (2003) 295-307.

1206 [77] S.Z. Imam, B. Karahalil, B.A. Hogue, N.C. Souza-Pinto, V.A. Bohr, Mitochondrial and nuclear 1207 DNA-repair capacity of various brain regions in mouse is altered in an age-dependent manner, Neurobiol. Aging 27 (2006) 1129-1136.

[78] G. Xu, M. Herzig, V. Rotrekl, C.A. Walter, Base excision repair, aging and health span. Mech. Ageing Dev. 129 (2008) 366-382.

[79] K.S. Rao, Dietary calorie restriction, DNA-repair and brain aging, Mol. Cell. Biochem. 253 (2003) 313-318.

[80] C.M. Gedik, G. Grant, P.C. Morrice, S.G. Wood, A.R. Collins, Effects of age and dietary restriction on oxidative DNA damage, antioxidant protection and DNA repair in rats, Eur. J. Nutr. 44 (2005) 263-272.

[81] P. Møller, M. Lohr, J.K. Folkmann, L. Mikkelsen, S. Loft, Aging and oxidatively damaged nuclear DNA in animal organs, Free Radic. Biol. Med. 48 (2010) 1275-1285. 

related increases in DNA repair and antioxidant protection: a comparison of the Boyd Orr Cohort of elderly subjects with a younger population group, Age Ageing 36 (2007) 521-526. Hanova, B. Pardini, J. Slyskova, L. Musak, G. De Palma, P. Soucek, K. Hemminki, Association of DNA repair polymorphisms with DNA repair functional outcomes in healthy human subjects, Carcinogenesis 28 (2007) 657-664.

[84] A.R. Trzeciak, J. Barnes, N. Ejiogu, K. Foster, L.J. Brant, A.B. Zonderman, M.K. Evans, Age, sex, and race influence single-strand break repair capacity in a human population, Free Radic. Biol. Med. 45 (2008) 1631-1641.

[85] A. Jensen, M. Løhr, L. Eriksen, M. Grønbæk, E. Dorry, S. Loft, P. Møller, Influence of the OGG1 Ser326Cys polymorphism on oxidatively damaged DNA and repair activity. Free Radic Biol Med 52: 118-125, 2012.

[86] P. Czarny, D. Kwiatkowski, M. Toma, J. Kubiak, A. Sliwinska, M. Talarowska, J. Szemraj, M. Maes, P. Galecki, T. Sliwinski, Impact of single nucleotide polymorphisms of base excision repair genes on DNA damage and efficiency of DNA repair in recurrent depression disorder, Mol. Neurobiol. 54 (2017) 4150-4159.

[87] H. Hoffmann, J. Högel, G. Speit, The effect of smoking on DNA effects in the comet assay: a meta-analysis, Mutagenesis 20 (2005) 455-466.

[88] D.T. Saha, B.J. Davidson, A. Wang, A.J. Pollock, R.A. Orden, R. Goldman, Quantification of DNA repair capacity in whole blood of patients with head and neck cancer and healthy donors by comet assay, Mut. Res. 650 (2008) 55-62.

[89] P. Vodicka, R. Kumar, R. Stetina, L. Musak, P. Soucek, V. Haufroid, M. Sasiadek, L. Vodickova, A. Naccarati, J. Sedikova, S. Sanyal, M. Kuricova, V. Brsiak, H. Norppa, J. Buchancova, K. Hemminki, Markers of individual susceptibility and DNA repair rate in workers exposed to xenobiotics in a tire plant, Environ. Mol. Mutagen. 44 (2004)283-292.

[90] G.P. Basten, S.J. Duthie, L.P. Lirie, N. Vaughan, M.H. Hill, H.J. Powers, Sensitivity of markers of DNA stability and DNA repair activity to folate supplementation in healthy volunteers, Brit. J. Cancer 94 (2006) 1942-1947.

[91] P. Riso, D. Martini, P. Møller, S. Loft, G. Bonacina, M. Moro, M. Porrini, DNA damage and repair activity after broccoli intake in young healthy smokers, Mutagenesis 25 (2010) 595-602.

[92] M. Tomasetti, R. Alleva, A.R. Collins, In vivo supplementation with coenzyme $Q_{10}$ enhances the recovery of human lymphocytes from oxidative DNA damage, FASEB J. 15 (2001) 14251427.

[93] A.R. Collins, V. Harrington, J. Drew, R. Melvin, Nutritional modulation of DNA repair in a human intervention study, Carcinogenesis 24 (2003) 511-515.

[94] S.B. Astley, R.M. Elliott, D.B. Archer, S. Southon, Evidence that dietary supplementation with carotenoids and carotenoid-rich foods modulates the DNA damage : repair balance in human lymphocytes, Br. J. Nutr. 91 (2004) 63-72.

[95] S.J. Duthie SJ, Folate and cancer: how DNA damage and DNA repair impact on colon carcinogenesis, J. Inherit, Metab. Dis. 34 (2011) 101-109.

[96] M. Milic, A. Frustaci, A. Del Bufalo, J. Sánchez-Alarcón, R. Valencia-Quintana, P. Russo, S. Bonassi, DNA damage in non-communicable diseases: A clinical and epidemiological perspective, Mutat. Res. 776 (2015) 118-127. 
[97] I. Talhaoui, B.T. Matkarimov, T. Tchenio, D.O. Zharkov, M.K. Saparbaev, Aberrant base excision repair pathway of oxidatively damaged DNA: Implications for degenerative diseases, 1264 Free Rad. Biol. Med. 107 (2017) 266-277.

1265 [98] M. Usman, E.V. Volpi, DNA damage in obesity: Initiator, promoter and predictor of cancer, Mutat. Res. Rev. Mutat. Res. 778 (2018) 23-37.

[99] T. Setayesh, A. Nersesyan, M. Mišík, F. Ferk, S. Langie, V.M. Andrade, A. Haslberger, S. Knasmüller, Impact of obesity and overweight on DNA stability: Few facts and many hypotheses, Res. Rev. Mutat. Res. 777 (2018) 64-91.

[100] O. Palyvoda, J. Polanska, A. Wygoda, J. Rzeszowska-Wolny, DNA damage and repair in lymphocytes of normal individuals and cancer patients: studies by the comet assay and micronucleus tests, Acta Biochim. Pol. 50 (2003) 181-190.

[101] Q. Shi, R.W.L. Godschalk, F.J. van Schooten, Inflammation and the chemical carcinogen benzo[a]pyrene: Partners in crime, Mutat. Res. 774 (2017) 12-24.

[102] P. Møller, L. Möller, R.W. Godschalk, G.D. Jones, Assessment and reduction of comet assay variation in relation to DNA damage: studies from the European Comet Assay Validation Group, Mutagenesis 25 (2010) 109-111.

[103] C. Johansson, P. Møller, L. Forchhammer, S. Loft, R.W. Godschalk, S.A. Langie, S. Lumeij, G.D. Jones, R.W. Kwok, A. Azqueta, D.H. Phillips, O. Sozeri, M.N. Routledge, A.J. Charlton, P. Riso, M. Porrini, A. Allione, G. Matullo, J. Palus, M. Stepnik, A.R. Collins, L. Möller, An ECVAG trial on assessment of oxidative damage to DNA measured by the comet assay, Mutagenesis 25 (2010) 125-132.

[104] L. Forchhammer, C. Johansson, S. Loft, L. Möller, R.W. Godschalk, S.A. Langie, G.D. Jones, R.W. Kwok, A.R. Collins, A. Azqueta, D.H. Phillips, O. Sozeri, M. Stepnik, J. Palus, U. Vogel, H. Wallin, M.N. Routledge, C. Handforth, A. Allione, G. Matullo, J.P. Teixeira, S. Costa, P. Riso, M. Porrini, P. Møller, Variation in the measurement of DNA damage by comet assay measured by 1287 the ECVAG inter-laboratory validation trial, Mutagenesis 25 (2010) 113-123.

1288

1289

1290

1291

1292

1293

1294

1295

1296

1297

1298

1299

1300

1301

1302

1303

1304

1305

1306

[105] C. Ersson, P. Møller, L. Forchhammer, S. Loft, A. Azqueta, R.W. Godschalk, F.J. van Schooten, G.D. Jones, J.A. Higgins, M.S. Cooke, V. Mistry, M. Karbaschi, D.H. Phillips, O. Sozeri, M.N. Routledge, K. Nelson-Smith, P. Riso, M. Porrini, G. Matullo, A. Allione, M. Stepnik, M. Ferlińska, J.P. Teixeira, S. Costa, L.A. Corcuera, A. López de Cerain, B. Laffon, V. Valdiglesias, A.R. Collins, L. Möller, An ECVAG inter-laboratory validation study of the comet assay: interlaboratory and intra-laboratory variations of DNA strand breaks and FPG-sensitive sites in human mononuclear cells, Mutagenesis 28 (2013) 279-286.

[106] A.R. Collins AR, A. Azqueta, S.A. Langie, Effects of micronutrients on DNA repair. Collins AR, Azqueta A, Langie SA . Eur. J. Nutr. 51 (2012) 261-279.

[107] C.K. Ho, S.W. Choi, P.M. Siu, I.F. Benzie, Effects of single dose and regular intake of green tea (Camellia sinensis) on DNA damage, DNA repair, and heme oxygenase-1 expression in a randomized controlled human supplementation study, Mol. Nutr. Food Res. 58 (2014) 13791383.

[108] S.W. Choi, V.T. Yeung, A.R. Collins, I.F. Benzie, Redox-linked effects of green tea on DNA damage and repair, and influence of microsatellite polymorphism in HMOX-1: results of a human intervention trial, Mutagenesis 30 (2015) 129-137.

[109] Q. Shi, L. Maas, C. Veith, F.J. Van Schooten, R.W. Godschalk, Acidic cellular microenvironment modifies carcinogen-induced DNA damage and repair, Arch. Toxicol. 91 (2017) 2425-2441. 

Møller, S. Loft, Oxidatively damaged DNA and its repair after experimental exposure to wood smoke in healthy humans, Mutat.Res. 642 (2008) 37-42.

[111] E.V. Bräuner, L. Forchhammer, P. Møller, J. Simonsen, M. Glasius, P. Wåhlin, O. Raaschou-Nielsen, S. Loft, Exposure to ultrafine particles from ambient air and oxidative stressinduced DNA damage, Environ. Health Perspect. 115 (2007) 1177-1182. damaged DNA in rats exposed by oral gavage to $\mathrm{C} 60$ fullerenes and single-walled carbon nanotubes, Environ. Health. Perspect. 117 (2009) 703-708.

[113] J. Bausinger, G. Speit, Induction and repair of DNA damage measured by comet assay in human T lymphocytes separated by immunomagnetic cell sorting, Mutat. Res. 769 (2014) 4248.

[114] F. Faust, F. Kassie, S. Knasmüller, R.H. Boedecker, M. Mann, V. Mersch-Sundermann, The use of the alkaline cometa assay with lymphocytes in human biomonitoring studies, Mutat. Res. 566 (2004) 209-229.

[115] D.J. McKenna, S.R. McKeown, V.J. McKelvey-Martin, Potential use of the comet assay in the clinical management of cancer, Mutagenesis 23 (2008) 183-190.

[116] E. Rojas, Y. Lorenzo, K. Haug, B. Nicolaissen, M. Valverde, Epithelial cells as alternative human biomatrices for comet assay, Front. Genet. 5 (2014) 386.

[117] R. Wiggins, P.J. Horner, K. Whittington, C.H. Holmes, Quantitative analysis of epithelial cells in urine from men with and without urethritis: implications for studying epithelial: pathogen interactions in vivo, BMC Res. Notes. 2 (2009) 139.

[118] F.J. Van Schooten, A. Besaratinia, S. De Flora, F. D'Agostini, A. Izzotti, A. Camoirano, A.J. Balm, J.W. Dallinga, A. Bast, G.R. Haenen, L. Van't Veer, P. Baas, H. Sakai, N. Van Zandwijk, Effects of oral administration of $\mathrm{N}$-acetyl-L-cysteine: a multi-biomarker study in smokers, Cancer Epidemiol. Biomarkers Prev. 11 (2002) 167-175.

[119] A. Besaratinia, L.M. Maas, E.M. Brouwer, J.C. Kleinjans, F.J. Van Schooten, Comparison between smoking-related DNA adduct analysis in induced sputum and peripheral blood lymphocytes, Carcinogenesis 21 (2000) 1335-1340.

1336

[120] J. Ge, S. Prasongtanakij, D.K. Wood, D.M. Weingeist, J. Fessler, P. Navasummrit, M. Ruchirawat, B.P. Engelward, CometChip: a high-throughput 96-well platform for measuring DNA damage in microarrayed human cells, J Vis Exp 92 (2014) e50607.

\section{Legends (figures and tables)}

Figure 1: Scheme of the cellular repair assay. Nucleoids can either be incubated with lesionspecific enzymes (to assess various specific DNA lesions) or not (to assess SBs). The formation and removal of DNA lesions is studied over time, requiring multiple cell incubations

Figure 2: Scheme of the in vitro repair assay. Substrate cells can be exposed to the photosensitizer Ro 19-8022 plus light to induce 8-oxodG lesions or to UV to induce primer dimers, allowing the assessment of BER and NER incision activity respectively. After lysis, gel- 
1350

1351

1352

1353

1354

1355

1356

1357

1358

1359

1360

1361

embedded nucleoids are incubated with protein extracts for cells in culture, blood or tissues. Subsequent standard single-cell gel electrophoresis reveals the SSBs introduced by the DNA repair enzymes. The addition of dNTPs to the extracts would allow to study DNA synthesis/ligation capacity in parallel to DNA incision activity.

Figure 3: Correlation between repair activities in extracts from human lymphocytes taken at different dates (approximately 2 months apart) and analysed using the BER (A) and NER (B) in vitro repair assay. Taken from [32], with permission.

Table 1. Overview of human DNA repair mechanims. Taken from [3], with permission.

Table 2. Correlation coefficients, $R$, for repair rates of 33 individuals at different sampling times (blood samples were taken approximately 4 weeks apart). ${ }^{*} p<0.05$. Adapted from [32], with permission.

Table 3. Inter-individual variation in repair activity using different assays. Data from samples taking at two occasions were available; mean values were used to estimate the range. Adapted from [12], with permission.

Table 4. Studies on association between age and DNA repair activity in leukocytes, lymphocytes or peripheral mononuclear blood cells.

Table 5. Studies on association between dietary factors and DNA repair activity in leukocytes, lymphocytes or peripheral mononuclear blood cells.

Table 6. Sources of exfoliated cells that can be collected in human biomonitoring studies 

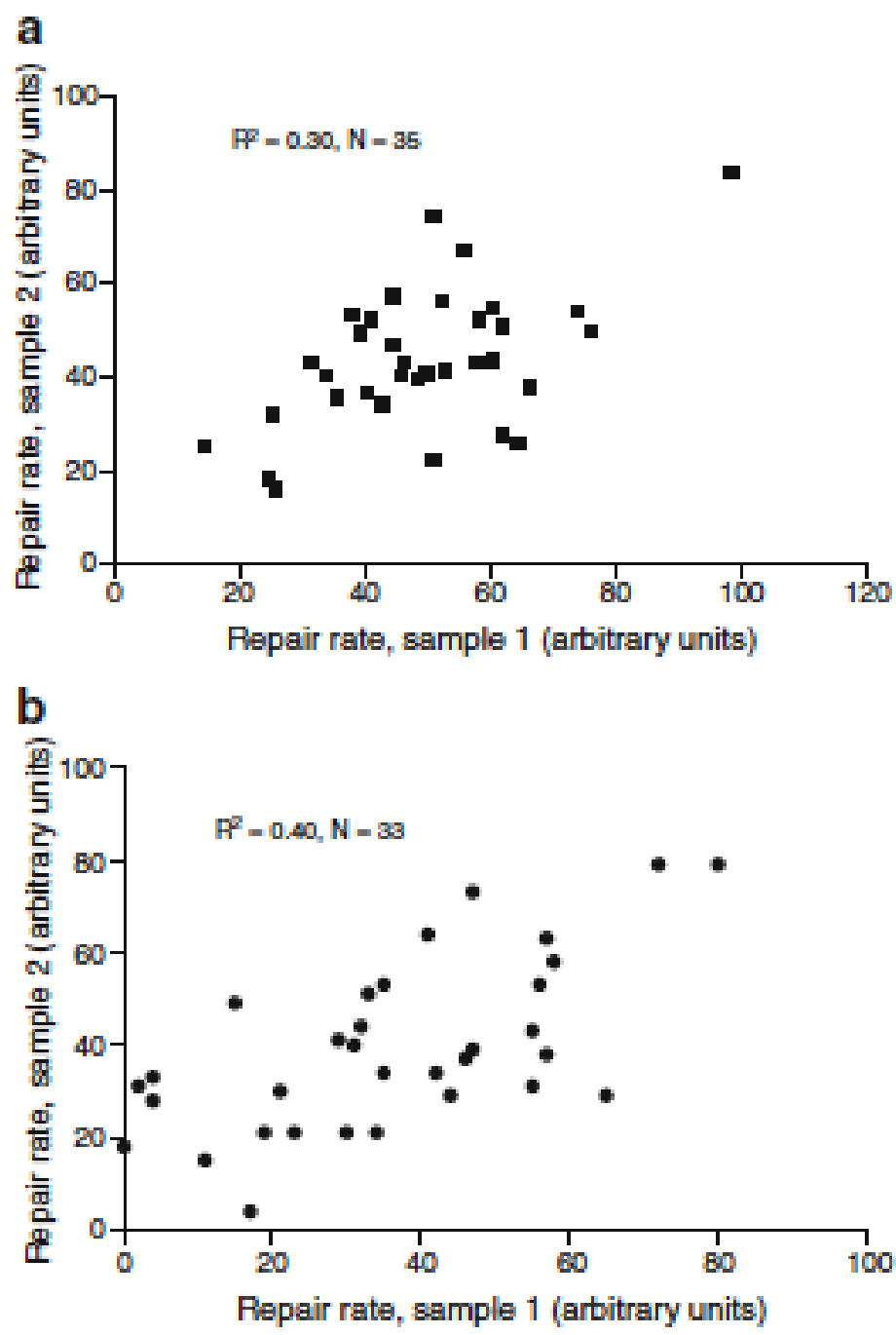


\begin{tabular}{|l|l|l|}
\hline \multicolumn{1}{|c|}{ Repair pathway } & \multicolumn{1}{|c|}{ Damage repaired } & \multicolumn{1}{c|}{ Sources of damage } \\
\hline Direct reversal & $\begin{array}{l}\text { Alkylated base O' } \text {-methyl- } \\
\text { guanine, pyrimidine dimers (by } \\
\text { photolyase) }\end{array}$ & $\begin{array}{l}\text { Alkylating agents, nitrosoureas, streptozotocin, UV(C) } \\
\text { light }\end{array}$ \\
\hline Base excision repair & $\begin{array}{l}\text { Oxidised bases, alkylated bases, } \\
\text { abasic/apurinic/apyrimidinic } \\
\text { sites, single-strand breaks }\end{array}$ & $\begin{array}{l}\text { Reactive oxygen species (ROS), alkylating agents, ionizing } \\
\text { radiation, spontaneous hydrolysis }\end{array}$ \\
\hline Nucleotide excision repair & $\begin{array}{l}\text { Bulky helix-distorting lesions, } \\
\text { intra-strand cross links, DNA- } \\
\text { protein cross links, inter-strand } \\
\text { cross links }\end{array}$ & $\begin{array}{l}\text { UV(C) light, cigarette smoke, dietary factors (aflatoxin, } \\
\text { poly-aromatic hydrocarbons (benzo(a)pyrene)) }\end{array}$ \\
\hline Mismatch repair & $\begin{array}{l}\text { Mismatched base pairs, small } \\
\text { insertion loops }\end{array}$ & $\begin{array}{l}\text { Replication errors, minor base modifications (oxidation, } \\
\text { alkylation) }\end{array}$ \\
\hline $\begin{array}{l}\text { Double-strand break repair (i.e., homologous } \\
\text { recombination and non-homologous end- } \\
\text { joining) }\end{array}$ & Double-strand breaks & lonising radiation, replication errors \\
\hline
\end{tabular}




\begin{tabular}{lccccc}
\hline & $\mathrm{T}=0$ & $\mathrm{~T} \approx 4$ weeks & $\mathrm{T} \approx 8$ weeks & $\mathrm{T} \approx 12$ weeks & $\mathrm{T} \approx 16$ weeks \\
\hline $\mathrm{BER}$ & & & & & \\
$\mathrm{T} \approx 4$ weeks & 0.25 & & & & \\
$\mathrm{~T} \approx 8$ weeks & $0.42^{*}$ & 0.11 & & & \\
$\mathrm{~T} \approx 12$ weeks & $0.40^{*}$ & $0.50^{*}$ & 0.30 & & \\
$\mathrm{~T} \approx 16$ weeks & $0.60^{*}$ & 0.08 & $0.62^{*}$ & $0.38^{*}$ & \\
$\mathrm{~T} \approx 20$ weeks & $0.50^{*}$ & $0.35^{*}$ & 0.12 & 0.32 & $0.47^{*}$ \\
\hline $\mathrm{NER}$ & & & & & \\
$\mathrm{T} \approx 4$ weeks & $0.40^{*}$ & & & & \\
$\mathrm{~T} \approx 8$ weeks & 0.32 & $0.60^{*}$ & & & \\
$\mathrm{~T} \approx 12$ weeks & $0.51^{*}$ & $0.64^{*}$ & $0.52^{*}$ & & \\
$\mathrm{~T} \approx 16$ weeks & $0.44^{*}$ & $0.54^{*}$ & $0.48^{*}$ & $0.40^{*}$ & \\
$\mathrm{~T} \approx 20$ weeks & $0.45^{*}$ & $0.42^{*}$ & 0.18 & 0.31 & $0.59^{*}$ \\
\hline
\end{tabular}




\begin{tabular}{|c|c|c|c|c|c|}
\hline Lesion repaired & Assay & $\mathbf{N}$ & Range (fold) & Source of variation & Reference \\
\hline AP-sites & Plasmid & 10 & 2.5 & $\begin{array}{l}\text { Healthy individuals (age: } 25-48 \text { years). Authors did not correlate repair } \\
\text { with other parameters. }\end{array}$ & {$[18]$} \\
\hline 8-OxoG & Oligonucleotide & 34 & 2 & $\begin{array}{l}\text { Healthy individual (age: 18-60). There was no difference in OGG1 activity } \\
\text { due to gender and smoking behaviour. Authors did not report age effect. } \\
\text { OGG1 polymorphism not associated with altered OGG1 activity. }\end{array}$ & [70] \\
\hline 8-OxoG & Oligonucleotide & 120 & 2.8 & $\begin{array}{l}\text { Healthy individuals. No significant differences between males and } \\
\text { females, or between smokers and non-smokers. OGG1 activity was } \\
\text { significantly lower in males older than } 55 \text { years compared to younger } \\
\text { subjects. This effect was not observed in females. }\end{array}$ & [24] \\
\hline 8-OxoG & $\begin{array}{l}\text { In vitro comet } \\
\text { assay }\end{array}$ & 35 & 3 & $\begin{array}{l}\text { Healthy individuals from intervention study (no effect of the intervention } \\
\text { on DNA repair capacity). No further data on individuals' characteristics } \\
\text { reported. Authors did not correlate repair with other parameters. }\end{array}$ & [32] \\
\hline 8-OxoG & $\begin{array}{l}\text { In vitro comet } \\
\text { assay }\end{array}$ & 40 & 41 & $\begin{array}{l}\text { Individuals from } 18 \text { to } 30 \text { years old. Association between endogenous SBs } \\
\text { and BER was not observed. Authors did not correlate repair with other } \\
\text { parameters.. }\end{array}$ & [71] \\
\hline $\begin{array}{l}\text { UV-induced } \\
\text { damage }\end{array}$ & $\begin{array}{l}\text { Host cell } \\
\text { reactivation } \\
\text { assay (HCRA): } \\
\text { catalase and } \\
\text { luciferase assay }\end{array}$ & 102 & $\begin{array}{l}4.7 \text { (luciferase } \\
\text { assay) } \\
7 \text { (catalase } \\
\text { assay) }\end{array}$ & $\begin{array}{l}\text { Healthy subjects (age: 19-79). Authors did analyze correlation with age } \\
\text { or other factors. }\end{array}$ & [72] \\
\hline $\begin{array}{l}\text { UV-induced } \\
\text { damage }\end{array}$ & $\begin{array}{l}\text { In vitro comet } \\
\text { assay }\end{array}$ & 33 & 7 & $\begin{array}{l}\text { Healthy individuals from intervention study (no effect of the intervention } \\
\text { on DNA repair capacity). No further data on individuals' characteristics } \\
\text { reported. Authors did not correlate repair with other parameters. }\end{array}$ & [32] \\
\hline $\begin{array}{l}\text { UV-induced } \\
\text { damage }\end{array}$ & $\begin{array}{l}\text { Host cell } \\
\text { reactivation }\end{array}$ & 63 & 11 & $\begin{array}{l}\text { Individuals from an intervention study (age: } 18-30, \text { no effect of the } \\
\text { intervention on DNA repair capacity). NER capacity was inversely } \\
\text { associated with age, endogenous DNA SBs and BMI (adiposity). }\end{array}$ & [73] \\
\hline Benzo(a)pyrene & $\begin{array}{l}\text { In vitro comet } \\
\text { assay }\end{array}$ & 8 & 10 & $\begin{array}{l}\text { Healthy individuals; no further data. Authors did not correlate repair with } \\
\text { other parameters. }\end{array}$ & [31] \\
\hline $\begin{array}{l}\text { BPDE- induced } \\
\text { damage }\end{array}$ & $\begin{array}{l}\text { Aphidicoline- } \\
\text { block cellular } \\
\text { comet assay }\end{array}$ & 122 & 40 & $\begin{array}{l}\text { Healthy people (age: } 19-48, \text { cropreserved lymphocytes). Authors did not } \\
\text { correlate repair with other parameters. }\end{array}$ & {$[51]$} \\
\hline
\end{tabular}





\begin{tabular}{|c|c|c|c|c|c|}
\hline $\begin{array}{l}\text { Country (age) number of } \\
\text { females (F) and males } \\
\text { (M) }\end{array}$ & Cell type & $\begin{array}{c}\text { Comet repair assay } \\
\text { (substrate) }\end{array}$ & Effect on DNA repair biomarker & Adjustment & Reference \\
\hline $\begin{array}{l}\text { Slovakia (21-88 years, } \\
227 \mathrm{M}, 161 \mathrm{~F}) \text { recruited } \\
\text { from factories with } \\
\text { occupational exposure to } \\
\text { asbestos, stone wool or } \\
\text { glass fibres and controls } \\
\text { matched for age, sex, } \\
\text { alcohol consumption and } \\
\text { smoking }\end{array}$ & $\begin{array}{l}\text { Lymphocytes } \\
\text { (frozen) }\end{array}$ & $\begin{array}{c}\text { In vitro repair } \\
\text { (Ro19-8022 + light, } \\
\text { Hela cells, } 10 \text { min } \\
\text { incubation) }\end{array}$ & $\begin{array}{l}\text { Positive association between age } \\
\text { and repair incision activity }(r= \\
0.1, P<0.05 \text {, correlation analysis } \\
\text { not specified) }\end{array}$ & $\begin{array}{l}\text { No control for } \\
\text { confounding (with } \\
\text { regard to age- } \\
\text { dependent effects } \\
\text { on DNA repair } \\
\text { incision activity) }\end{array}$ & [69] \\
\hline $\begin{array}{l}\text { UK (young ( } 20-35 \text { years), } \\
\text { middle ( } 63-70 \text { years) or } \\
\text { old ( } 75-82 \text { years), } n=97, \\
\text { MF). Sampled from areas } \\
\text { near Bristol, London, } \\
\text { Wisbech, Aberdeen and } \\
\text { Dundee }\end{array}$ & $\begin{array}{l}\text { Lymphocytes } \\
\text { (frozen) }\end{array}$ & $\begin{array}{l}\text { In vitro repair } \\
\text { (Ro19-8022 + light, } \\
\text { Hela cells } 10 \text { min } \\
\text { incubation) }\end{array}$ & $\begin{array}{l}\text { Positive association between age } \\
\text { and repair incision activity ( } r= \\
0.25, \mathrm{P}=0.06 \text {, Pearson } \\
\text { correlation). Statistically } \\
\text { significant group difference when } \\
\text { tested by ANOVA }\end{array}$ & $\begin{array}{l}\text { No control for } \\
\text { confounding }\end{array}$ & [82] \\
\hline $\begin{array}{l}\text { Czech Republic (41 } \pm 11 \\
\text { years, } 183 \mathrm{M}, 61 \mathrm{~F} \text { ) } \\
\text { recruited in local } \\
\text { administration, medical } \\
\text { centres and various } \\
\text { branches of plastic } \\
\text { industry }\end{array}$ & $\begin{array}{l}\text { Lymphocytes } \\
\text { (fresh for } \\
\text { repair of DNA } \\
\text { strand breaks, } \\
\text { frozen for in } \\
\text { vitro repair } \\
\text { assay) }\end{array}$ & $\begin{array}{l}\text { In vitro repair } \\
\text { (Ro19-8022 + light, } \\
\text { Hela cells, } 10 \text { min } \\
\text { incubation) } \\
\text { Repair of gamma } \\
\text { radiation induced } \\
\text { DNA strand breaks } \\
\text { (5 Gy) }\end{array}$ & $\begin{array}{l}\text { No association between age and } \\
\text { repair incision activity and } \\
\text { gamma radiation-induced DNA } \\
\text { strand breaks (results not shown, } \\
\text { type of control for confounding } \\
\text { not specified in detail) }\end{array}$ & $\begin{array}{l}\text { Analysed by both } \\
\text { simple and } \\
\text { multivariate } \\
\text { regression analysis }\end{array}$ & [83] \\
\hline $\begin{array}{l}\text { USA (30-64 years, } 48 \mathrm{~F} \text {, } \\
48 \mathrm{M} \text { ) of White and } \\
\text { African America race }\end{array}$ & $\begin{array}{l}\text { PBMCs } \\
\text { (frozen) }\end{array}$ & $\begin{array}{l}\text { Repair of gamma } \\
\text { radiation induced } \\
\text { DNA strand breaks } \\
(6.3 \mathrm{~Gy})\end{array}$ & $\begin{array}{l}\text { Positive association between age } \\
\text { and repair activity in White } \\
\text { females ( } r=0.55, P<0.01 \text { ) and } \\
\text { borderline statistical significance } \\
\text { ( } r=-0.40, P=0.06 \text {, linear } \\
\text { regression) in African-American } \\
\text { females. No effect in White or } \\
\text { African-American males }\end{array}$ & $\begin{array}{l}\text { Matched in sex and } \\
\text { race strata }\end{array}$ & [84] \\
\hline
\end{tabular}




\begin{tabular}{|c|c|c|c|c|c|}
\hline $\begin{array}{l}\text { Denmark ( } 18-83 \text { years, } \\
40 \mathrm{M}, 38 \mathrm{~F} \text { ) from a } \\
\text { national health survey in } \\
\text { Copenhagen }\end{array}$ & $\begin{array}{l}\text { PBMCs } \\
\text { (frozen) }\end{array}$ & $\begin{array}{c}\text { In vitro repair } \\
\left(\mathrm{KBrO}_{3}, \mathrm{THP}-1 \text { cells }\right. \\
45 \text { min incubation) }\end{array}$ & $\begin{array}{c}\text { Inverse association between age } \\
\text { and repair incision activity in } \\
\text { women, but not in men. Decline } \\
\text { in repair activity per year was } \\
0.65 \% \text { per year ( } 95 \% \text { Cl: } 0.16 \% \text { - } \\
1.14 \% \text { ) in multivariate regression } \\
\text { analysis } \\
\end{array}$ & $\begin{array}{c}\text { Sex, body mass index } \\
\text { (or waist-hip ratio), } \\
\text { blood pressure, } \\
\text { cholesterol, } \\
\text { triglycerides, Hb1Ac, } \\
\text { C-reactive protein, } \\
\text { smoking and alcohol } \\
\end{array}$ & [30] \\
\hline
\end{tabular}




\begin{tabular}{|c|c|c|c|c|c|}
\hline $\begin{array}{l}\text { Country (age) number of } \\
\text { females (F) and males } \\
\text { (M) }\end{array}$ & Cell type & $\begin{array}{c}\text { Comet repair assay } \\
\text { (substrate) }\end{array}$ & Effect on DNA repair biomarker & $\begin{array}{c}\text { Effect on } \\
\text { phytochemical }\end{array}$ & Reference \\
\hline $\begin{array}{l}\text { Sequential study of non- } \\
\text { smokers ( } 20-50 \text { years, } n= \\
6, M, \text { Scotland) ingesting } \\
100 \mathrm{mg} / \text { day of } \mathrm{CoQ}_{10} \text { for } \\
1 \text { week and a subsequent } \\
\text { washout period of } 1 \\
\text { week }\end{array}$ & $\begin{array}{l}\text { Lymphocytes } \\
\text { (fresh) }\end{array}$ & $\begin{array}{c}\text { In vitro repair } \\
\text { (Ro19-8022 + light, } \\
\text { lymphocytes, } 20 \\
\text { min incubation) }\end{array}$ & $\begin{array}{l}\text { Increased repair incision activity } \\
\text { after supplementation compared } \\
\text { to pre-supplementation. } \\
\text { Decreased levels compared to } \\
\text { supplementation period, } \\
\text { although not statistically } \\
\text { significant, after } 1 \text { week washout } \\
\text { period }\end{array}$ & $\begin{array}{c}\text { Increased } \operatorname{CoQ}_{10} \\
\text { concentration in plasma }\end{array}$ & [92] \\
\hline $\begin{array}{l}\text { Cross-over study on } \\
\text { healthy non-smoking } \\
\text { subjects ( } 26-54 \text { years, } n= \\
\text { 14, MF, Scotland) } \\
\text { ingesting 1, } 2 \text { or } 3 \\
\text { kiwifruits/day for } 3 \\
\text { weeks }\end{array}$ & $\begin{array}{l}\text { Lymphocytes } \\
\text { (fresh) }\end{array}$ & $\begin{array}{c}\text { In vitro repair } \\
\text { (Ro19-8022 + light, } \\
\text { Hela cells, } 10 \text { min } \\
\text { incubation) }\end{array}$ & $\begin{array}{l}\text { Increased repair incision activity } \\
\text { after consumption of kiwifruits } \\
\text { (similar effect of 1-3 } \\
\text { kiwifruits/day) }\end{array}$ & $\begin{array}{c}\text { Increased plasma } \\
\text { concentration of } \\
\text { vitamin C concentration }\end{array}$ & [93] \\
\hline $\begin{array}{l}\text { Placebo-controlled } \\
\text { parallel trial on non- } \\
\text { smokers (18-50 years, } \mathrm{n}= \\
20, \mathrm{UK}) \text { ingesting tablets } \\
\text { with a-carotene }(3.7 \mathrm{mg}) \\
\text { and } \beta \text {-carotene }(8.2 \mathrm{mg}) \\
\text { for } 3 \text { weeks }\end{array}$ & $\begin{array}{l}\text { Lymphocytes } \\
\text { (fresh) }\end{array}$ & $\begin{array}{c}\text { Repair of } \mathrm{H}_{2} \mathrm{O}_{2} \\
\text { induced DNA } \\
\text { strand breaks (100 } \\
\mu \mathrm{M})\end{array}$ & $\begin{array}{l}\text { DNA repair of DNA strand breaks } \\
\text { over a } 4 \mathrm{~h} \text { incubation period (no } \\
\text { repair in cells from the placebo } \\
\text { group). Groups of subjects with } \\
\text { intake of cooked carrots, } \\
\text { mandarin oranges and vitamin C } \\
\text { tablets were included in the } \\
\text { study, but the results are not } \\
\text { reported (risk of reporting bias) }\end{array}$ & $\begin{array}{l}\text { Increased plasma } \\
\text { concentration of } \beta \text { - } \\
\text { carotene }\end{array}$ & [94] \\
\hline $\begin{array}{l}\text { Placebo-controlled } \\
\text { parallel trial on non- } \\
\text { smokers ( } 20-60 \text { years, } n= \\
61, M F, U K) \text { ingesting } \\
\text { folic acid ( } 1.6 \mathrm{mg} / \text { day) for } \\
12 \text { weeks }\end{array}$ & $\begin{array}{l}\text { Lymphocytes } \\
\text { (not specified) }\end{array}$ & $\begin{array}{c}\text { In vitro repair } \\
\text { (Ro19-8022 + light, } \\
\text { CHO cells } 20 \text { min } \\
\text { incubation) }\end{array}$ & $\begin{array}{l}\text { Unaltered levels of repair incision } \\
\text { activity in the whole study } \\
\text { population. A restricted analysis } \\
\text { of the quartile with lowest } \\
\text { baseline red cell folate } \\
\text { concentration showed a } \\
\text { reduction of repair incision } \\
\text { activity in the folate }\end{array}$ & $\begin{array}{l}\text { Increased 5- } \\
\text { methyltetrahydrofolate } \\
\text { concentration in } \\
\text { plasma, erythrocytes, } \\
\text { and lymphocytes }\end{array}$ & [90] \\
\hline
\end{tabular}




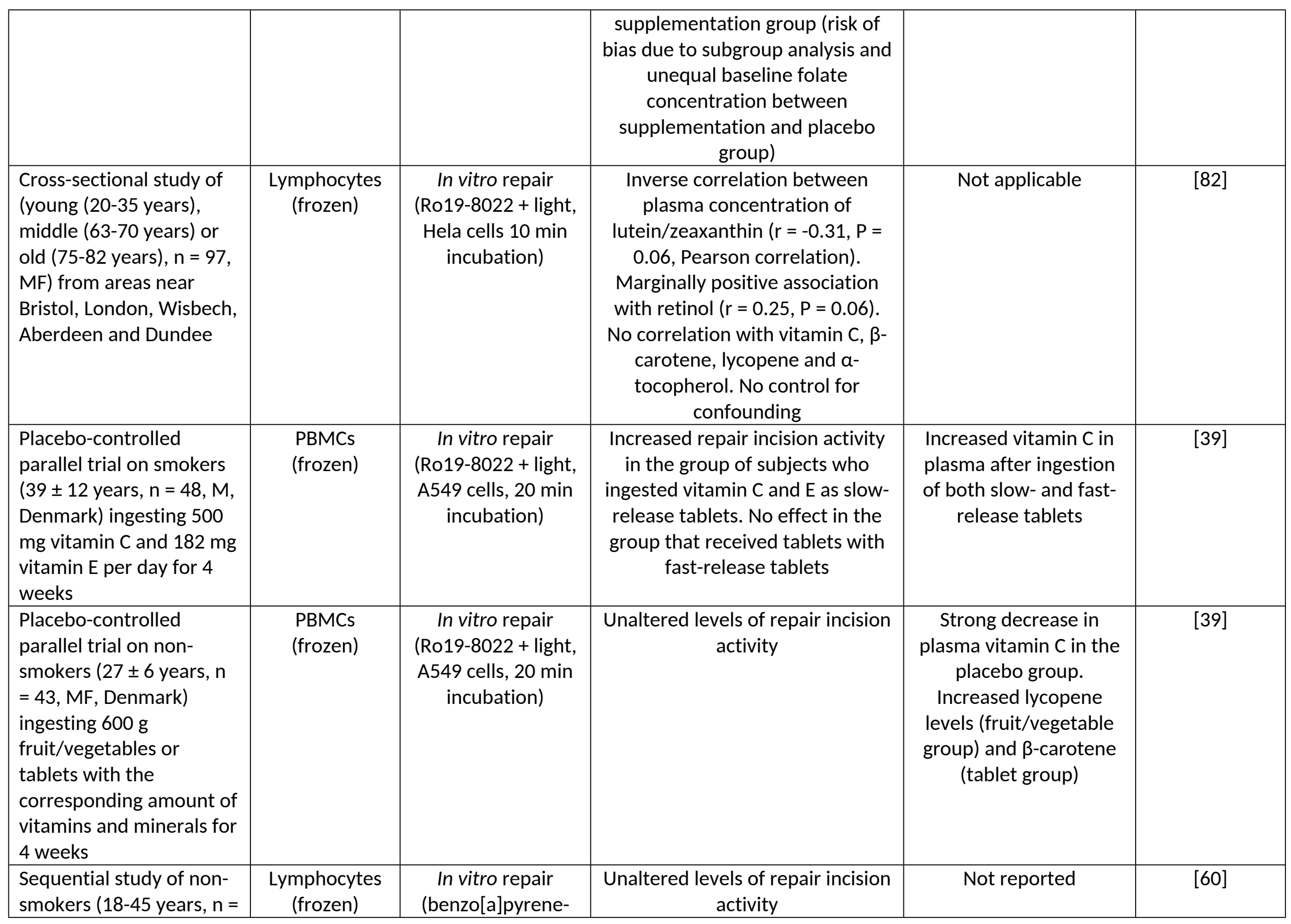




\begin{tabular}{|c|c|c|c|c|c|}
\hline $\begin{array}{l}\text { 36, MF, Netherlands), } \\
\text { selected according to } \\
\text { ERCC1 genotype, } \\
\text { ingesting blueberry and } \\
\text { apple juice for } 4 \text { weeks } \\
\text { after a 5-day washout } \\
\text { period }\end{array}$ & & $\begin{array}{l}\text { diolepoxide, cells } \\
\text { or incubation not } \\
\text { reported) }\end{array}$ & & & \\
\hline $\begin{array}{l}\text { Placebo-controlled } \\
\text { parallel trial on non- } \\
\text { smokers (18-30 years, } \mathrm{n}= \\
48, \mathrm{MF}, \mathrm{UK} \text { ) ingesting a } \\
\text { supplement ( } 100 \mu \mathrm{g} \\
\text { Selenium, } 450 \mu \mathrm{g} \text { vitamin } \\
\mathrm{A}, 450 \mu \mathrm{g} \text { retinol, } 90 \mathrm{mg} \\
\text { vitamin C and } 30 \mathrm{mg} / \\
\text { vitamin } \mathrm{E} \text { ) for } 6 \text { weeks }\end{array}$ & $\begin{array}{l}\text { Lymphocytes } \\
\text { (frozen) }\end{array}$ & $\begin{array}{l}\text { In vitro repair } \\
\text { (Ro19-8022 + light, } \\
\text { Hela cells, } 20 \text { min } \\
\text { incubation) }\end{array}$ & $\begin{array}{l}\text { Unaltered levels of repair incision } \\
\text { activity }\end{array}$ & Not reported & [71] \\
\hline $\begin{array}{l}\text { Cross-over study on } \\
\text { smokers ( } 22 \pm 3 \text { years, } \\
\text { sex not specified, Italy) } \\
\text { ingesting steamed } \\
\text { broccoli ( } 250 \mathrm{~g} / \text { day) for } \\
10 \text { days }\end{array}$ & $\begin{array}{l}\text { PBMCs } \\
\text { (frozen) }\end{array}$ & $\begin{array}{c}\text { In vitro repair } \\
\text { (Ro19-8022 + light, } \\
\text { A549 cells, } 20 \text { min } \\
\text { incubation) }\end{array}$ & $\begin{array}{c}\text { Unaltered levels of repair incision } \\
\text { activity }\end{array}$ & $\begin{array}{c}\text { Increased plasma } \\
\text { concentration of folate } \\
\text { and lutein. Unaltered } \\
\text { levels of } \beta \text {-carotene }\end{array}$ & [91] \\
\hline $\begin{array}{l}\text { Placebo-controlled } \\
\text { parallel trial on smokers } \\
\text { (45-75 years, } n=69, \mathrm{M} \text {, } \\
\text { Norway) ingesting } \\
\text { kiwifruit or a } \\
\text { phytochemical-rich diet } \\
\text { for } 8 \text { weeks }\end{array}$ & $\begin{array}{l}\text { Lymphocytes } \\
\text { (frozen) }\end{array}$ & $\begin{array}{l}\text { In vitro repair } \\
\text { (Ro19-8022 + light, } \\
\text { substrate cell not } \\
\text { reported, } 20 \text { min } \\
\text { incubation; UV-C, } \\
\text { substrate cell not } \\
\text { reported, } 30 \text { min) }\end{array}$ & $\begin{array}{c}\text { Increased base excision (Ro19- } \\
8022+\text { light) and decreased } \\
\text { nucleotide excision (UV-C) repair } \\
\text { in both kiwifruit and } \\
\text { phytochemical-rich diet group }\end{array}$ & $\begin{array}{c}\text { Increased vitamin C } \\
\text { (both groups). Increased } \\
\beta \text {-carotene and } \\
\text { tocopherol in the } \\
\text { phytochemical-rich } \\
\text { group }\end{array}$ & [62] \\
\hline
\end{tabular}




\begin{tabular}{|c|c|c|}
\hline Target tissue & Surrogate tissue & How to obtain cells \\
\hline Bladder & Exfoliated epithelial cells & - Isolate from urine \\
\hline \multirow[t]{3}{*}{ Upper respiratory tract } & Buccal cells & \multirow{3}{*}{$\begin{array}{ll}\text { - } & \text { Mouth rinse or scraping } \\
\text { - Nasal lavage } \\
\text { - }\end{array}$} \\
\hline & Nasal epithelial cells & \\
\hline & Mouth cells & \\
\hline Lower respiratory tract & Lung derived cells & $\begin{array}{l}\text { - Isolate cells from induced } \\
\text { or spontaneously produced } \\
\text { sputum } \\
\text { - Broncho-alveolar lavage }\end{array}$ \\
\hline Colon & Exfoliated epithelial cells & - Isolate from stool \\
\hline \multirow[t]{3}{*}{ Mammary } & Exfoliated epithelial cells & Isolate from \\
\hline & & - Nipple aspirate \\
\hline & & $\begin{array}{ll}\text { - } & \text { Ductal lavage } \\
\text { - } & \text { Breast milk }\end{array}$ \\
\hline \multirow[t]{2}{*}{ Prostate / testis } & Epithelial cells & \multirow[t]{2}{*}{ - Isolate from ejaculate } \\
\hline & spermatozoa & \\
\hline Other tissues & & - Biopsy (invasive) \\
\hline
\end{tabular}

